\title{
The Potential Application of Giant Reed (Arundo donax) in Ecological Remediation
}

\author{
Deng Zhang ${ }^{1}$, QianWen Jiang ${ }^{1}$, DanYang Liang ${ }^{2}$, Shixun Huang ${ }^{1 *}$ and Jianxiong Liao ${ }^{1 *}$ \\ ${ }^{1}$ Guangxi Key Laboratory of Plant Conservation and Restoration Ecology in Karst Terrain, Guangxi Institute of Botany, Guangxi \\ Zhuang Autonomous Region and Chinese Academy of Sciences, Guilin, China, ${ }^{2}$ College of Tourism \& Landscape Architecture \\ (College of Plant and Ecological Engineering), Guilin University of Technology, Guilin, China
}

OPEN ACCESS

Edited by:

Chunhao Gu,

University of Delaware, United States

Reviewed by:

Kuldeep Bauddh,

Central University of Jharkhand, India Mihaly Czako, University of South Carolina, United States

*Correspondence: Shixun Huang hsx@gxib.cn Jianxiong Liao liaojianx@163.com

Specialty section: This article was submitted to Toxicology, Pollution and the Environment, a section of the journal Frontiers in Environmental Science

Received: 12 January 2021 Accepted: 16 April 2021

Published: 13 May 2021

Citation:

Zhang $D$, Jiang $Q$, Liang $D$, Huang $S$ and Liao J (2021) The Potential Application of Giant Reed (Arundo donax) in Ecological Remediation.

Front. Environ. Sci. 9:652367. doi: 10.3389/fenvs.2021.652367
Giant reed is known as one of the most important energy plants as a consequence of its huge dry biomass production. It can be used for bioenergy or biopolymer production. Thus, it can replace maize and reduce the production cost of biomass and electricity. Giant reed and its products have different uses in industry. The use of giant reed as a raw material to obtain cellulose past for the production of rayon viscose and paper. Thanks to the flexible and strong of the material, giant reed can be used in the manufacture of fishing rods, brass musical instruments, canes and construction supplies. One of the most important characteristics of giant reed is that it shows strong growth capability in different soils with wide ranges of $\mathrm{pH}$, salinity and high heavy metal contents and can be used for ecological remediation. Giant reed was able not only to decontaminate polluted soils with heavy metals, but also to purify the wastewater and decrease the $\mathrm{pH}$ and make red mud safer. Here, we review the available evidence regarding the utilization of giant reed in the field of phytoremediation and discuss the potential application of giant reed combined with advanced remediation technologies in ecological remediation.

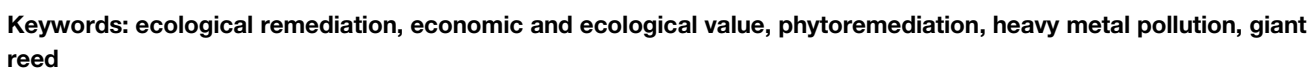
reed

\section{INTRODUCTION}

With the coming of the industrial revolution, humans were able to advance further into the $21 \mathrm{st}$ century. At present, the industry is a critical component of the world's economy. However, at the same time, the industrial processes also cause environmental pollution. It accounts for more than half of the total emissions of some key air pollutants and greenhouse gases, as well as other critical ecological impacts, including the release of pollutants to water and soil (Muradian and MartinezAlier, 2001; Wang et al., 2019). Consequently, these pollutants can pose a health risk to humans and other organisms.

The discharge of excessive amount of heavy metals is one of the most severe environment pollutions. The toxicity of heavy metals is well documented for its impairment of plant growth and human health. Therefore, it is necessary to eliminate excessive amounts of heavy metals in soil and water to avoid negative consequences. Various conventional methods have been used to remove heavy metals, such as chemical precipitation, solvent extraction, membrane filtration, ion change, electrochemical removal and coagulation etc. (Burakov et al., 2018). However, questions have been raised to query these techniques in term of incomplete removal, low efficiency and costly disposal etc. Compared to conventional methods, phytoremediation has excellent potential to overcome those 
drawbacks, improving the treatment efficiency and cut the expense. It has been reported that some hyperaccumulator plants can accumulate a large number of heavy metals. For example, Alyssum bertolonii can accumulate $\mathrm{Ni}$ up to about $10,000 \mu \mathrm{g} \mathrm{g}^{-1}$ or $1 \%$ (Reeves et al., 2018). Soil salinization is another global environmental problem that could damage land quality and limit plant growth. It is estimated that over half of the irrigated farmlands are seriously impacted by soil salinization ( $\mathrm{Li}$ et al., 2018). Although the use of chemical amendment, for example, use $\mathrm{Ca}$ to replace exchangeable $\mathrm{Na}$, or apply organic amendments such as farm manure, poultry manure and plant ash to reduce the soil $\mathrm{pH}$ may be a practical strategy to improve soil remediation (Tejada et al., 2006; Dahlawi et al., 2018), the high cost and less efficiency of these methods were the main obstacles that limit their application (Nouri et al., 2017). Alternatively, halophytes are ideal plants for salt remediation of soil. For example, Tecticornia indica and Suaeda fruticosa, which can eliminate redundant salts from soil, and thus these plants are popularly used for the soil remediation (Rabhi et al., 2010). Water is essential for life on Earth. Any pollutants or contaminants which find their way into water will soon find their way into the bodies of plants and animals. Contaminated water is one of the most common forms of environmental pollution, not to mention one of the most damaging to the health of living organisms, entering bodies through drinking, contact, or uptake from roots. Water pollution can either be directly through the discharging of waste into a body of water such as a lake, river or the sea, or it can be indirect in that it is not deliberately disposed of into a watercourse but finds its way there. The most common cause of water pollution is human activity including industry, agriculture and livestock farming, rubbish and fecal water dumping. To abate water pollution, various treatments such as adsorption, biodegradation, coagulation, ion-exchange, and oxidation processes have been evaluated. However, the practice of these methods is very complexity (Jain et al., 2018; Shahid et al., 2019). Constructing wetlands to remediate wastewater is an efficient strategy because of its eco-friendly and low operational cost (Wang et al., 2018). This strategy mainly uses the plant-bacteria synergism to clean the organic matter, microorganisms, nitrogen, and phosphorus in the water.

Based on the above information, we can conclude that plants with excellent pollutant adsorption capacity have great potential in ecological remediation. In the following, we introduce the characterization of giant reed (Arundo donax) in the field of phytoremediation and discuss the potential application of giant reed combined with advanced remediation technologies in ecological remediation.

\section{ORIGIN AND REPRODUCTION OF GIANT REED}

Giant reed is a tall perennial rhizomatous grass that can reach $10 \mathrm{~m}$ in height (Barreca et al., 2019). Owing to its fast growth and great biomass, giant reed had been attracted the farmers and researchers attention to use for multi-purpose (Perdue, 1958; Bell, 1998). For a long time, the stem of the giant reed was used to make paper (Perdue, 1958). In Italy, giant reed has been used in industry since 1930, when a company registered a trademark to obtain cellulose for producing rayon viscose and paper (Facchini, 1941). The European "Giant reed Network" has been established since January 1997. The project, within the framework of the FAIR Program, has been designed to generate information about this plant's capacity to be brought into EU agriculture for energy and pulp production (Lewandowski et al., 2003). Due to its considerable growth capacity in different soils with wide ranges of $\mathrm{pH}$, salinity, and trace metal contents, giant reed was used to absorb heavy metals and improve saline alkali soil in recent years (Herrera-Alamillo and Robert, 2012; Quinn et al., 2015). Giant reed is suitable for energy production because of the high biomass yield, which can reach to $37.7 \mathrm{t}$ dry matter per ha and per year (Angelini et al., 2009). Among the different biomass crops for producing renewable energy to reduce greenhouse gas emissions due to fossil fuels, the giant reed is considered the best candidate (Di Mola et al., 2018). It is an ideal plant for dealing with extreme situations of soil conditions and water availability (Figure 1).

Because of its vast economic value, giant reed is widely planted in subtropical regions of the world, such as Southern Europe, North Africa, Australia, and America (Guo and Miao, 2010). Giant reed does not produce seed in many areas because the further development of the embryo is restricted (Balogh et al., 2012; Nikhade and Makde, 2014; Alshaal et al., 2015). The propagation of giant reed can be divided into rhizomes or stem cuttings and in vitro biotechnology methods.

Planting time on stem cuttings has a significant influence on the survival rate of the giant reed. Tang (2000) used the stem of the giant reed as propagules about February or March, and the survival rate reached $97 \%$. However, the survival rate of cutting with the lateral branches of giant reed is not high. Luo et al. (2018) used different types and concentrations of plant hormones to treat the lateral branches of giant reed, and the highest survival rate was only $50 \%$. Rhizomes are easy to generate roots in wet environments and produce new plant clones. The propagation of giant reed is more commonly used fragments of rhizomes.

Compared with rhizomes or stem cuttings, the efficiency of in vitro biotechnology methods is higher. Gubišová et al. (2016) report that stem segments containing an axillary bud of the giant reed can produce about 700 rooted and acclimatized plants in one year starting from one axillary bud on Murashige and Skoog medium supplemented with $0.5 \mathrm{mg} \mathrm{l}^{-1}$ 6-benzyladenine or $0.2 \mathrm{mg} \mathrm{l}^{-1}$ thidiazuron. Marton and Czako (2002) suggest that the immature inflorescences of giant reed are sterilized and then cultured in vitro to produce totipotent tissue from which mass propagation of plantlets is possible. Herrera-Alamillo and Robert (2012) use axillary buds from the lateral stems cultured in liquid medium supplemented with indole 3 -acetic acid and kinetin to produce 900 plants from a single mother plant in 4 months Cavallaro et al. (2011) describe a protocol for the large-scale in vitro propagation of giant reed by adventitious bud formation. The technical system of callus induction, differentiation, and plant regeneration can significantly increase the reproduction coefficient of plants. Chen et al. (2016) report that Murashige and Skoog medium supplemented with $0.2 \mathrm{mg} \mathrm{l}^{-1}$ naphthaleneacetic 


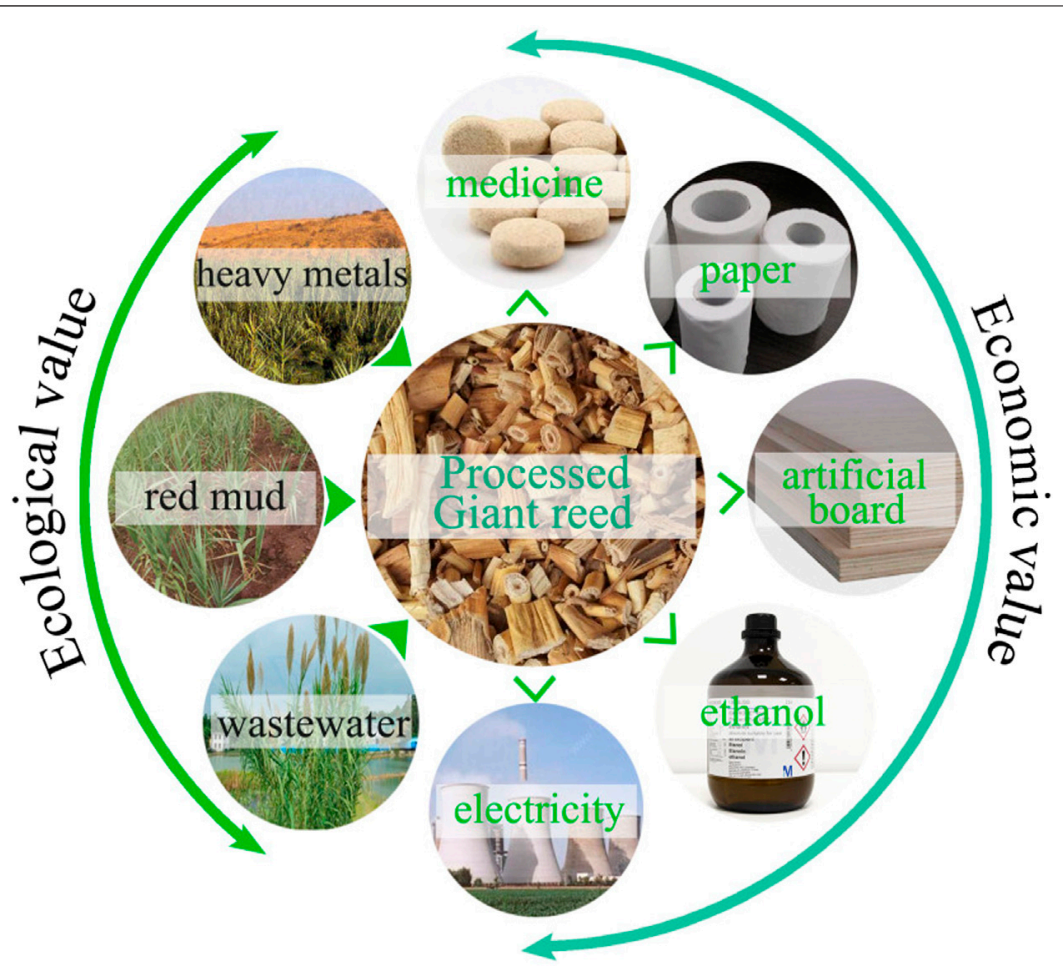

FIGURE 1 | Comprehensive application of giant reed.

acid and $2.0 \mathrm{mg} \mathrm{l}^{-1}$ 6-benzyladenine are used for the best callus differentiation medium in turn the bud differentiation stage reached $40.00 \%$, while Yang et al. (2016) suggest that the callus (with an improved quality as well as an increased quantity) were transferred on the Murashige and Skoog medium with $0.5 \mathrm{mgl}^{-1}$ kinetin and $1.0 \mathrm{mgl}^{-1} \quad 6$ benzyladenine, on which both shoots and roots were simultaneously induced with a large quantity. The regenerated plants grow to more than $5.0 \mathrm{~cm}$ and transfer to Murashige and Skoog medium with $0.2 \mathrm{mg} \mathrm{l}^{-1}$ naphthaleneacetic acid and $1 \mathrm{~g} \mathrm{l}^{-1}$ activated carbon. The rate of rooting was $100 \%$ for 7 days, and the average root number was four, and the length of the roots was $2-4 \mathrm{~cm}$ (Xian et al., 2018). The rooted seedings, which with roots $2-3 \mathrm{~cm}$, were transplanted from culturing seedlings to fine river sand, yellow soil or humus soil after one week-day's treatment. The survival percent reaches $98 \%$ after a month.

\section{THE ECONOMIC VALUE OF GIANT REED}

\section{Giant Reed Used as an Energy Crop}

Giant reed has a wide range of adaptations and can be planted in marginal areas where crops cannot grow (Roberto, 2012). It grows very fast and can grow to $6 \mathrm{~m}$ or even higher (Liao et al., 2017). The mature crop shows average annual production rates of $3 \mathrm{~kg}$ dry matter $\mathrm{m}^{-2}$, with maximum values acquired in fertilized plots and during winter harvest time (Angelini et al., 2005). Giant reed is a very suitable source of biomass because of its low cost and high productivity (Corno et al., 2014; Corno et al., 2015). Research shows that giant reed can replace maize and reduce the production cost of biomass and electricity (Corno et al., 2016). Giant reed stems can be transformed into useful, value-added reliable products through pyrolysis at appropriate conditions (Basso et al., 2005). Solid biofuels are conducive to preservation and transportation. Giant reed has good potential for biogas production through anaerobic digestion (AD). Among them, cellulose has the highest degradation rate and the most significant contribution to biogas production (Yang and Li, 2014).

\section{Giant Reed Used as an Industrial Material}

Its peculiar characteristics, such as its large diffusion on the territory, its stem's lightness combined with its adequate mechanical strength, and its high cellulose content, have allowed different industrial uses of giant reed (Perdue, 1958; Speck and Spatz, 2004; Barreca, 2012). Because of its advanced eco-friendly pulping and bleaching technology, giant reed has become an excellent substitute for wood fibers to meet pulp and paper products' rapid growth (Shatalov and Pereira, 2006). The fibers of giant reed possess high tensile strength and suitable raw material for particleboard production (Flores et al., 2011). The stem of the giant reed can be converted into activated carbon by various technologies, which shows excellent performance in wastewater treatment (Ahmed, 2016). In the Mediterranean region, giant reed has been traditionally employed to build fences and temporary shelters for men and animals, or as a prop for plants and as windbreak or shading barrier (Barreca and Fichera, 2013). Thanks to the lightness of the material, walls can 
be erected even by farmers or breeders with modest tools (Barreca, 2012). Because of widespread and locally abundant, giant reed is widely used and has a greater diversity of uses in Cyprus's northwest. The culms are used to make baskets, tables, fishing equipment, musical instruments, candy bow, chandelier, distaff, heddle, knife, and fence (Barreca, 2012).

\section{Giant Reed Used as Medicine}

Modern pharmacological studies have proved the plants' role in treating diseases, reflected in current plant origin drug therapy. The use of medicinal plants to treat diseases has witnessed such treatments and increased awareness of the importance of using natural resources in the pharmaceutical industry (El Sheikha, 2017). Giant reed is considered as one of the medicinal plants. It was reported that aqueous extracts of the reed nodes, which contain the white hemicellulose membrane, and demonstrated a marked dose-dependent response for anti-biofilm activity, both in preventing MRSA biofilm formation and disrupting established biofilms (Quave et al., 2008). The antimicrobial effects of methanolic extracts of 14 medicinal plant species were examined comparing to conventional therapeutic antibiotics against standard bacterial strains (Staphylococcus aureus, Micrococcus luteus, Klebsiella pneumoniae, Escherichia coli, and Pseudomonas eroginosa). Among the four medicinal plants, the giant reed extract has the most significant effect on Escherichia coli and Pseudomonas eruginosa (Al-Snafi, 2015). Besides, the tender shoots can be used for the treatment of fever, wound suppuration, ear infection, typhoid, pneumonia and asthma (Sinha, 1996; Singh, 2003; Dhiren and Singh, 2015). Extractions of biologically active components from giant reed shoot is regarded as good anti-galactagogue, depurative, diaphoretic, emollient, hypertensive, hypotensive, and sudorific (Duke and Wain, 1981). In addition, the root of giant reed is also an alternative herbal medicine used as diaphoretic, emollient, diuretic, and cancer, dropsy, and headache (Mir et al., 2018).

\section{PHYTOREMEDIATION POTENTIALS OF GIANT REED}

\section{Heavy Metal}

With fast urbanization and industrialization, heavy metal pollution has become one of the utmost environmental severe issues that influence human health (Zhao et al., 2018). In the past 5 decades, more than 30,000 tons of $\mathrm{Cr}$ and 800,000 tons of $\mathrm{Pb}$ have been released into the environment around the world (Yang et al., 2018). Heavy metal pollution has an essential impact on crop yield and quality and affects the air and water environment and even human health. Many of them are toxic even at deficient concentrations, which are cytotoxic and carcinogenic, and mutagenic. Joint committee of World Health Organization (WHO) and Food and Agriculture Organization (FAO) on food additives (JCEFA) has set the maximum tolerable intake for $\mathrm{As}, \mathrm{Cd}, \mathrm{Pb}$, and $\mathrm{Cr}$ as $2,1,6.03$, and $3.32 \mu \mathrm{g} / \mathrm{kg}$ body weight/ day, respectively (Dubey et al., 2018). Excessive levels of heavy metals can cause health risks, for instance, 1) the concentrations of $\mathrm{Hg}$ in whole blood reach $10 \mu \mathrm{g} / \mathrm{L}$ may lead to lung damage; kidney damage, proteinuria, allergy, and amalgam disease, 2) the dietary intake of $\mathrm{Cd}$ reach $0.01 \mathrm{mg} / \mathrm{kg} /$ day can affect kidney functioning, 3) intaking of $\mathrm{Ni}$ from contaminated food reach $5 \mathrm{mg} / \mathrm{kg} /$ day can affect renal functioning, and so on (Rai et al., 2019). Accumulation of heavy metals on soil can cause direct or indirect reduction of plant growth by adversely affecting various physiological and molecular activities of plants (Tiwari and Lata, 2018). The current research suggests that the maximum soil concentration for different heavy metal (loids) were as follows: As ranged from a maximum of $11-34 \mathrm{mg} / \mathrm{kg}$, Cd from 0.15 to $21.84 \mathrm{mg} / \mathrm{kg}, \mathrm{Cu}$ from 16 to $713 \mathrm{mg} / \mathrm{kg}$, Ni from 25 to $740 \mathrm{mg} / \mathrm{kg}$, $\mathrm{Pb}$ from 25 to $2025 \mathrm{mg} / \mathrm{kg}$, and $\mathrm{Zn}$ from 25 to $3,925 \mathrm{mg} / \mathrm{kg}$ (O'Connor et al., 2018). However, the tolerance of most plants for safe limits of heavy metals is not high. Guideline for safe limits of some heavy metal as follow: Cd from 3 to $6 \mathrm{mg} / \mathrm{kg}, \mathrm{Cu}$ from 135 to $270 \mathrm{mg} / \mathrm{kg}, \mathrm{Pb}$ from 250 to $500 \mathrm{mg} / \mathrm{kg}, \mathrm{Zn}$ from 300 to $600 \mathrm{mg} / \mathrm{kg}$, Ni from 75 to $150 \mathrm{mg} / \mathrm{kg}$ (Nagajyoti et al., 2010). In high concentrations, heavy metals negatively impact the growth, biomass, and photosynthesis of plants and compromise sustainable food production (Etesami, 2018). As a result of heavy metals have detrimental effects on plants and humans. Recently, the remediation of heavy metal pollution has aroused people's concern. So far, several efficient methods have been reviewed for the removal of heavy metals such as chemical precipitation, adsorption, ion exchange, reverse osmosis, phytoremediation, bioremediation, membrane technology, and electrochemical treatment, etc. (Dixit et al., 2015). They can be classified into two main groups, including physicochemical and biological techniques. Key factors influencing the applicability and selection of such technologies are capital investment and operational cost, plant flexibility, and reliability and environmental impact, etc. (Fu and Wang, 2011). Physicochemical approaches include chemical precipitation, adsorption, ion exchange, reverse osmosis, membrane technology, and electrochemical treatment. These techniques are rapid but inadequate, high cost, intensive labor, altered soil properties, and disturbance of soil native microflora (Ali et al., 2013). Moreover, most of these techniques are ineffective when the concentration of heavy metals is below $100 \mathrm{mg} / \mathrm{L}$ (Ahluwalia and Goyal, 2007). Compared with physicochemical, biological remediation has many advantages, such as natural process, environmentally friendly, low cost, and high public acceptance (Ullah et al., 2015). Biological remediation use microorganisms and plants to remove toxic contaminants from the environment (Singh et al., 2009). Living or dead microorganisms can be used for the remediation of heavy metals. Among these microorganisms, bacteria, fungi, and algae are most widely used, for example, bacteria can remediate $\mathrm{Hg}, \mathrm{Pb}, \mathrm{Cr}, \mathrm{Cu}, \mathrm{Zn}$, and $\mathrm{Cd}$, fungi can remediate $\mathrm{Pb}, \mathrm{Cr}, \mathrm{Cu}, \mathrm{Co}$, and $\mathrm{Cd}$, algae can remediate $\mathrm{Pb}, \mathrm{Cr}, \mathrm{Cu}$, and $\mathrm{Cd}$ (Yin et al., 2019). Phytoremediation is an emerging green technology used of metallophytes and related soil microorganisms to reduce the concentration or toxic effects of heavy metals in the environment. Remediation of a metal-contaminated climate by phytoremediation has received extensive attention because it is cost-effective, efficient, resource-conserving, and eco-friendly (Baker et al., 
1994; Sumiahadi and Acar, 2018). Heavy metal removal from contaminated sites using different phytoremediation methods has been initiated worldwide since the last decade, including phytoremediation of organic, inorganic and radionuclides. This sustainable and cheap process is rapidly evolving into a viable alternative to traditional remedies and most suitable for developing countries (Ghosh and Singh, 2005).

Recently, the accumulation of heavy metals by giant reed attracted more and more attention from various fields of science and engineering and became a hot researching spot (Borso et al., 2018; Coppa et al., 2020; Delplace et al., 2020). Giant reed has promising ability to uptake wide variety of metals viz. $\mathrm{Pb}, \mathrm{Cd}, \mathrm{Mo}, \mathrm{As}, \mathrm{Zn}, \mathrm{Cu}, \mathrm{Ni}, \mathrm{Co}, \mathrm{Fe}, \mathrm{Mn}, \mathrm{Cr}, \mathrm{Hg}$, Al etc. from the environment (Miao et al., 2012; Delplace et al., 2020; Danelli et al., 2021). It is a promising candidate for the phytoremediation of $\mathrm{Zn}$-/Cr-contaminated soil (Li et al., 2014). Biomass obtained in $\mathrm{Zn}$ and $\mathrm{Cr}$ contaminated soils presented higher ash content and higher $\mathrm{Zn} / \mathrm{Cr}$ content than biomass from non-contaminated soils (Barbosa et al., 2013; Barbosa et al., 2015). Pu et al. (2017) reported that despite the oxidative stress involved in the mechanism of $\mathrm{Cd}$ toxicity associated with the high transport of $\mathrm{Cd}$ in giant reed, its photosynthetic system was not harmed. When giant reed grown on surface soil and irrigated with mixed heavy metal solutions of $\mathrm{Cd}(\mathrm{II})$ and $\mathrm{Ni}(\mathrm{II})$, the examined parameters, namely, stem height and diameter, number of nodes, fresh and dry weight of leaves, and net photosynthesis (Pn) were not affected (Papazoglou et al., 2005). Mahmood (2010) report that giant reed can extract arsenic (As) and mercury $(\mathrm{Hg})$ in sufficient amounts, and Cano-Ruiz et al. (2020) report that giant reed showed a broad tolerance to cadmium $(0.5 \mathrm{mM})$, chromium $(0.2 \mathrm{mM})$, cooper $(2 \mathrm{mM})$, nickel $(0.5 \mathrm{mM})$ and lead $(1 \mathrm{mM})$. Guarino et al. (2020) reported that giant reed can remove As through high and efficient volatilization. Biomass obtained in $\mathrm{Pb}$ contaminated soils presented higher ash content and lead content than biomass from non-contaminated soils (Sidella et al., 2013). Based on the findings of Domokos-Szabolcsy et al. (2018), giant reed can be identified as the first monocot hyperaccumulator of selenium. Some researchers find that the presence of chelating agent, organic fertilizer and mycorrhizal fungi have an impact on the ability to accumulate metals for giant reed. Atma et al. (2017) investigate that the addition of EDTA to the treatment increased plant uptake of arsenic. Other researchers also aimed at finding that compost fertilization and mycorrhizal fungi inoculations increase the metal uptake of giant reed (Fiorentino et al., 2013; Liu et al., 2017; Sarathambal et al., 2017).

The remediation mechanism from plants is distinct. According to growth potential in HM-contaminated sites, they can be classified into five main groups including plant extraction, plant degradation, plant stabilization, plant volatilization and rhizosphere filtration (Mukhopadhyay and Maiti, 2010; Ali et al., 2013; Thakur et al., 2016; Saxena et al., 2019). Recent studies show that giant reed shows good phytostabilization capability in the short-term while long-term can be used in phytoextraction processes (Cristaldi et al., 2020). The $\mathrm{pH}$ of the soil and the presence of chelating agents like mugineic acid family phytosiderophores (MAs) can mobilize metal ions into the soil solution. Metal ions can be taken up by the root of giant reed and come in contact with the cell wall. Giant reed can translocate the heavy metals to above-ground shoots or leaves and produce a large quantity of plant biomass that can be easily harvested (Figure 2). Various kinds of heavy metals can be extracted and accumulated in various organs (e.g., root, stem, leaf) by giant reed. Numerous studies have shown that the root is

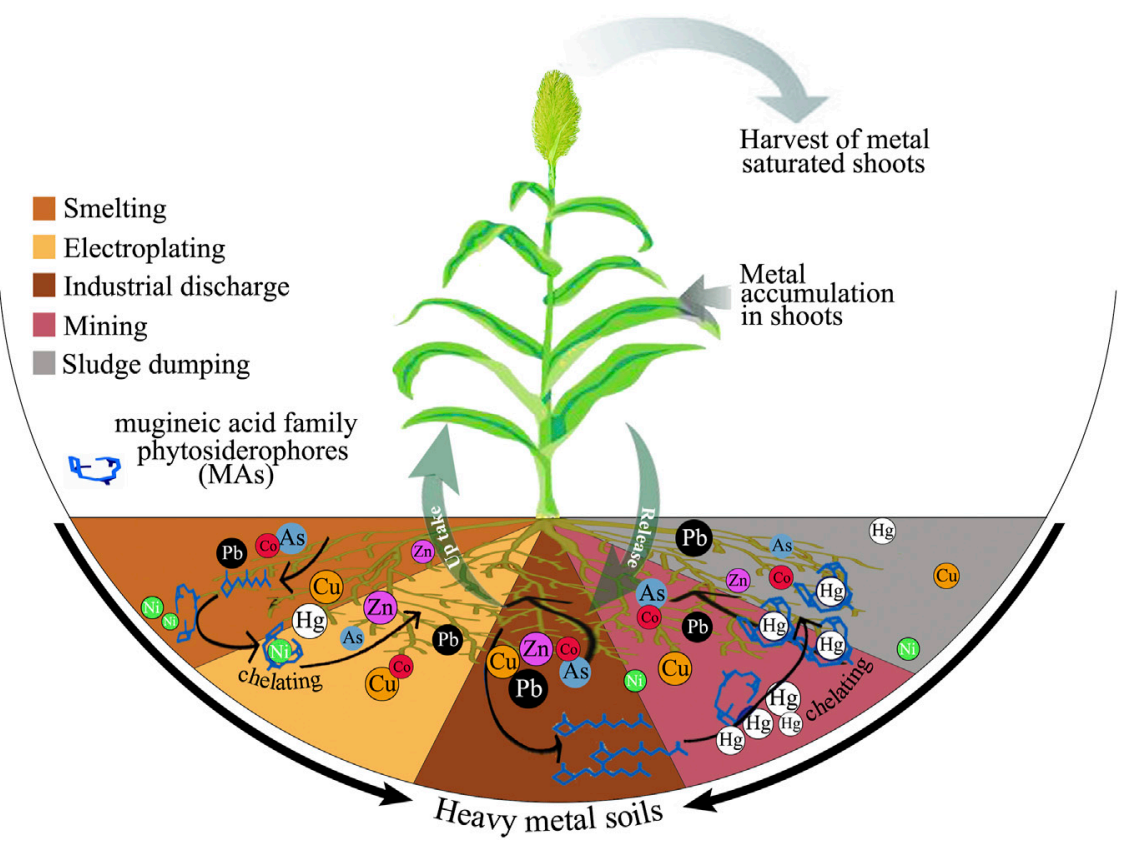

FIGURE 2 | The process of heavy metals accumulation in giant reed. 
the highest concentration organ, and the stem is the lowest concentration organ (Table 1). However, the most inferior concentration organ is still a matter of debate that leaf can be the most deficient concentration organ when heavy metals in soil are out of threshold limit value (Cristaldi et al., 2020). It can become hyperaccumulator plants and absorb metal contaminants from the ground and translocate them to erial plant parts (Baker et al., 2000). In general, heavy metals exert multiple inhibitory effects on photosynthesis at several structural and metabolic levels (Clijsters and Van Assche, 1985). However, giant reed does not die after exposure to metal and show no visible signs of stress, and the photosynthetic rate of giant reed is not affected by heavy metals (Papazoglou et al., 2005). The phytoextraction process has a significant advantage for giant reed because most heavy metals are accumulated in the roots. In this way, the use of the upper parts (e.g., shoots and leaves) of giant reed is not affected, and the concentration of heavy metals in the soil can be reduced by collecting the roots of giant reed.

Previous research reported the mechanized harvest of the upper parts of giant reed. Curt et al. (2013) report that the strategy of two-step harvesting: stalk cutting and crushing and biomass collection and baling with this specific machinery is feasible. Assirelli et al. (2019) provide good results using a shredding machine for giant reed harvesting. Comparing to the mechanized harvest of the upper parts of giant reed, the roots of giant reed collecting are still a difficult task. Assirelli et al. (2013) use a modified stump grinder for in situ rhizome extraction. However, this method obtains most of the rhizomes with variable length, ranging between 4.4 and $6.4 \mathrm{~cm}$, and most of the rhizomes were not excavated in the soil. It is an excellent way to digging rhizomes with a Noble sweep plow to a $0.30 \mathrm{~m}$ depth (San Martín et al., 2019). Because the rhizome depth of giant reed is $5-30 \mathrm{~cm}$ under the soil surface, this method can obtain almost entirely of rhizomes. Due to the low volatility of heavy metals, pyrolysis is an excellent way to extract heavy metals from the roots of giant reed. Grottola et al. (2019) report that the metals recovery is in the temperature range 653-873 K under steam assisted slow pyrolysis conditions.

\section{Water Treatment}

Water is one of the major issues humanity must tackle to achieve human society's sustainable development (Zhang et al., 2018). Although the total amount of water is enough on the Earth, the amount of drinkable water is limited. Surface and groundwater in many parts of the world are contaminated and not suitable for drinking (Gupta et al., 2012). The primary sources of water

TABLE 1 | Types and locations of giant reed accumulating heavy metals.

\begin{tabular}{|c|c|c|c|c|}
\hline Metal type & Concentration organs & Highest concentration organ & Lowest concentration organ & References \\
\hline $\mathrm{Hg}$ & Root, stem, leaf & Root & Leaf & Cristaldi et al. (2020) \\
\hline $\mathrm{Cd}$ & Root, stem, leaf & Root & Stem & Guo and Miao (2010) \\
\hline $\mathrm{Cu}$ & Root, stem, leaf & Root & Stem & Han and Wang (2007) \\
\hline $\mathrm{Pb}$ & Root, stem, leaf & Root & Stem & Guo and Miao (2010) \\
\hline $\mathrm{Fe}$ & Root, stem, leaf & Root & Stem & Castaldi et al. (2018) \\
\hline $\mathrm{Ni}$ & Root, stem, leaf & Root & Stem & Bonanno (2012), Mabhungu et al. (2019) \\
\hline $\mathrm{Al}$ & Root, stem, leaf & Root & Stem & \\
\hline As & Root, stem, leaf & Root & Stem & \\
\hline $\mathrm{Cr}$ & Root, stem, leaf & Root & Stem & \\
\hline $\mathrm{Mn}$ & Root, stem, leaf & Root & Stem & \\
\hline $\mathrm{Zn}$ & Root, stem, leaf & Root & Stem & \\
\hline
\end{tabular}
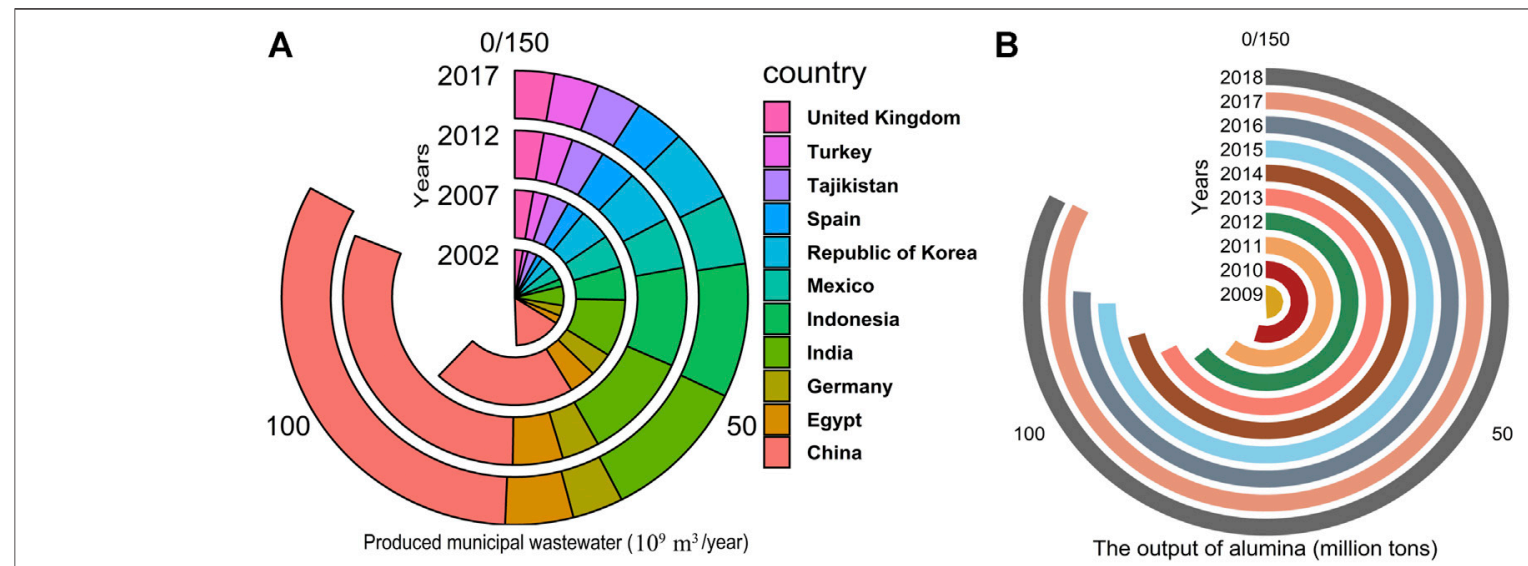

FIGURE 3 | Produced municipal wastewater in different countries (A) and the output of alumina in the world (3B). 
pollution come from industry, household, agricultural activities, and environmental and global changes. From 2002 to 2017, the total amount of municipal wastewater discharge in different countries uptrend (Figure 3A). In some developing countries, such as China, India, Indonesia, these countries produce much industrial wastewater and need to spend much money to treat this wastewater (This figure results from global information system on water and agriculture: http://www.fao.org/aquastat/statistics/ query/results.html). Wastewater treatment had been a concern in the Bronze Age (ca 3,200-1100 BC) in Crete, Aegean Islands, and Indus Valley civilizations (Salgot and Folch, 2018). Since the 1950s, wetlands had been used for water purification around the world. Emergy assessment, a measure of the environmental and human economic resource utilization, showed that wetland systems used much fewer materials than conventional wastewater treatment. Wetland systems can rely on microbes and plants' ecological action for their efficacy and improve energy independence (Nelson et al., 2001). Wetlands are divided into natural and constructed wetlands. Because of environmental issues, natural wetlands are not always available where treatment is needed (Jenssen et al., 1993). Using constructed wetlands (CW), ecological concerns are reduced, and systems can be built on-site and more easily customized to facilitate specific treatment needs. In constructed wetlands, plants can stabilize the bed's surface, provide the right physical filtration conditions, transport gases, release oxygen to the rhizosphere, absorb inorganic compounds, organic pollutants, and plant metabolites, and release organic compounds (Stottmeister et al. , 2003). Of course, not all plants are suitable for use in constructed wetlands. Plants need to meet the general requirements: 1) not causing significant weed or disease risks or risking to the ecological or genetic integrity of the surrounding natural ecosystems; 2) are well tolerant to local growing environments, pests, and diseases; 3) growing fast and having high biomass productivity; 4) removing of contaminants through direct assimilation and storage, or by enhancement of microbial transformations such as nitrification (through oxygen release from the root zone) and denitrification (by the production of carbon substrates) (Tanner, 1996).

Giant reed is an excellent plant for water purification. Wang et al. (2008) tested the removal efficiency of chemical oxygen demand (COD), total nitrogen (TN), and total phosphorus (TP) in rural domestic sewage by seven kinds of aquatic plants (Arundo donax, Triarrhena sacchariflora, Acorus calamus, Phragmites communis, Iris pseudacorus, Lythrum salicaria, and Sagittaria trifolia), and the result shows that giant reed has the strongest purification ability. Giant reed has higher removal rates for total suspended solids (TSS) than some aquatic plants (Toscano et al., 2015). The planted filter of giant reed allows better elimination of Escherichia coli (E. coli) than Pennisetum purpureum Schumach (Fidele and Audra, 2020) and previous study has shown that giant reed planted in gravel-based constructed wetlands (CWs) can remove up virtually $100 \%$ of $E$. coli (Idris et al., 2012a). It shows excellent organic pollutant removal, macronutrient, removal microbiological removal, and heavy metal (Leto et al., 2013; Jesus et al., 2017; Pu et al., 2018), giant reed can be used to treat various polluted waters (Liao et al., 2017). Giant reed shows excellent purification efficiency when used to treat micropolluted river water, secondary municipal wastewaters for crop irrigation, dairy factory stormwater, and winery wastewater (salinity up to $9 \mathrm{dS} / \mathrm{m}$ ) (Williams et al., 2008, 2009; Idris et al., 2012b; Xie et al., 2012; Barbagallo et al., 2014). Moreover, giant reed can be used as a source of biomass production when it is used to treat polluted waters. Mavrogianopoulos et al. (2002) report that giant reed stem biomass production in pig's waste is higher than the ordinary production in the soil. Irrigation with urban wastewater increased the biomass yield of three energy crops (Typha latifolia, Arundo donax, and Phragmites australis) and the biomass productivity of giant reed was much higher than those of T. latifolia and P. australis (Czakó and Márton, 2011; Zema et al., 2012). Giant reed can uptake pollutants from wastewater and accumulate pollutants in different parts. Cui and Wang (2013) got the nitrogen and phosphorus content of different parts of giant reed. There is a quantitive relationship of stem $<$ root $<$ leaves and root $<$ stem $<$ leaves, respectively, for the total nitrogen content and the total phosphorus content in the plant. Previous study reports the potential of giant reed for phytoextraction of heavy metals from synthetic wastewater and traces element concentrations decreased according to the pattern of root $>$ leaf > stem (Mirza et al., 2010; Bonanno, 2012). Pollutants can be removed from wastewater by harvesting giant reed. The harvested giant reed can also be used to produce biomethane for energy and digestate for plant nutrition through anaerobic digestion process (Shilpi et al., 2019). A major barrier to the use of giant reed for water purification is its invasive properties in riparian ecosystems. Because giant reed hardly produces viable seed and its clumping rhizome growth habit, its ability to spread is limited. Giant reed's rapid clonal spread can be attributed to flood dispersal of rhizome and culm fragments. It is necessary to avoid the use of giant reed for treatment polluted rivers that are subject to flooding.

\section{Red Mud Improvement}

As the name implies, the red mud is brick red in color and slimy, with an average particle size of fewer than $10 \mu \mathrm{m}$, and a few particles larger than $20 \mu \mathrm{m}$ can also be available (Paramguru et al., 2004). Red mud is the primary waste material produced during alumina production following the Bayer's process. Depending on the quality of the raw material processed, 1-2.5 tons of red mud is generated per ton of alumina produced (Paramguru et al., 2004). From 2009 to 2018, the output of alumina has nearly $40 \%$ growth in the world (An, 2019) (Figure 3B). China has become the leader in aluminum production and use (Hu et al., 2018). It causes the production of red mud to increase dramatically. Although many methods having been used to neutralize bauxite residues, cost remains an important consideration. Nowadays, dry stacking is one of the most popular disposal practices for red mud (Khairul et al., 2019). The main environmental impacts of red mud are its high alkalinity, salinity, and sodicity. Besides, the high alkalinity, salinity, and sodicity may be an immediate risk to plant growth. The $\mathrm{pH}$ of red mud can be up to 11 or more, due to presence of $\mathrm{NaOH}$ and $\mathrm{Na}_{2} \mathrm{CO}_{3}$ (1-6\%, w/w) (Brunori et al., 2005; Sahu et al., 2010). The selected plant species should survive high salinity and alkalinity conditions to build vegetation on the residue. However, 
very few plant species are able to survive on substrates with high $\mathrm{pH}, \mathrm{EC}$, and $\mathrm{Na}$ concentrations (Xue et al., 2016).

Without human intervention, the phytoremediation of red mud deposits is a slow process (Mishra and Pandey, 2019). Planting potentially successful plant species can accelerate ecological succession and restore soil fertility. Halophytes show the greatest potential to ameliorate bauxite residues (Xue et al., 2016). At present, giant reed is not considered to be a halophyte because it mainly invades freshwater habitats, but its salt tolerance has been confirmed (Pompeiano et al., 2017; Sánchez et al., 2017; Di Mola et al., 2018). Giant reed exhibits high tolerance to saline conditions and significant adaptability to salt accumulation in the soil (Verslues et al., 2006). Giant reed can maintain adequate $\mathrm{K}^{+}$and $\mathrm{Ca}^{2+}$ to counteract high salinity influence. The accumulation of $\mathrm{Na}^{+}$in leaf tissues under $\mathrm{Na}+$ stress was lower than that in roots during the experiment, and $\mathrm{Na}^{+}$decreased under leaf/root salinity (Balogh et al., 2012). However, in consideration of the accumulation of $\mathrm{Na}^{+}$and $\mathrm{Cl}^{-}$ in the leaves, the compartmentalization mechanism (for instance, vacuole storage) is likely to assist giant reed after exposure to salt toxicity once $\mathrm{Na}^{+}$and $\mathrm{Cl}^{-}$have been inevitably absorbed and translocated to the leaf tissues (Pompeiano et al., 2017). The results of biomass production, nutrient removal, salt tolerance, weed risk, and carbon sequestration with saline brewery wastewater show that giant reed is suitable for growing on saline soil (Williams et al., 2008). More importantly, giant reed can still grow well in the alkaline soils of $\mathrm{pH} 9-10$ and reduce alkaline soils' $\mathrm{pH}$. Giant reed has phytoremediation potential to grow in red mud containing high $\mathrm{pH}, \mathrm{EC}$, and trace metals. Red mud and red mud control soil in a 1:1 ratio positively affect on the height and biomass of reeds (Alshaal et al., 2013).

\section{CONCLUSION AND FUTURE CHALLENGES}

This paper reviews the application of giant reed in production and ecological remediation. It can absorb heavy metals, treat wastewater, improve red mud, and is a valuable raw material for many products. Genetic diversity has low among populations of giant reed that originated from different territories due to asexual reproduction (Antal et al., 2018). Therefore, it is of great significance to directly modify the expression of specific genes, making giant reed even more competitive than other energy crops.

Plant breeding can be considered a coevolution between humans and plants. People caused changes in the plants that were used for production and life. In turn, those new plant types allowed changes in human populations to take place. The core of plant breeding is to choose a better type among the varieties, yield, and quality of the edible portion; easy to grow, harvest, and process; resistance to environmental stress; and insect resistance (Breseghello and Coelho, 2013). Standard breeding methods include hybrid breeding, mutation breeding, haploid (polyploid) breeding, genetic engineering breeding. Among them, hybrid breeding is the preferred breeding method for many crops (Kempe and Gils, 2011). Hybrid breeding is a remarkable success story in maize, sunflower, sorghum, beets, and rye (Longin et al., 2012). As DNA's understanding has expanded and its importance for plant characteristics, breeders have taken matters into their own hands. Instead of waiting for spontaneous mutations to occur in DNA, they began mutation breeding in the 1930s (Bradshaw, 2017). Through this breeding, changes to plant DNA can be applied at a much higher frequency. Mutation breeding is an essential method for improving crops, with more than 3,200 mutant cultivars produced worldwide thus far (FAO/IAEA Mutant Variety Database) (Yamaguchi, 2018). Polyploidy is an intriguing phenomenon in plants that have provided an essential pathway for evolution and speciation (Bukhari and Kour, 2019). Polyploidy breeding can be used as a critical tool for developing new crop species, producing larger fruit or other parts to obtain more yield and profits, improving the resistance of plant organisms and abiotic organisms.

In the past 20 years, genetically engineered development has improved transgenic plants' speed and accuracy compared to traditional plant breeding. The knowledge of the essential genes transferred by transgenic plants is higher than that of conventional breeding. Transgenic technologies to develop cassava with enhanced resistance to viral diseases and insect pests improved nutritional content, modified and increased starch metabolism, and reduced cyanogenic content of processed roots (Taylor et al., 2004). Tobacco and Arabidopsis plants transformed with Escherichia coli mtlD encoding a mannitol-1-phosphate dehydrogenase accumulated mannitol. These plants have increased tolerance to high salinities than control plants (Bajaj et al., 1999). Liu et al. (2013) transferred the ScNHX1 (encoding vacuolar membrane $\mathrm{Na}+\mathrm{H}+$ antiporter from Suaeda corniculata) and ScVP (encoding vacuolar $\mathrm{H}+$ -PPase from $S$. corniculata) genes into alfalfa plants, and the results showed that transgenic alfalfa plants co-expressing $S c V P /$ ScNHX1 showed higher salt and saline-alkali tolerance compared with wild-type plants. Di et al. (2015) introduced the gene encoding the betaine aldehyde dehydrogenase from Atriplex micrantha into the maize inbred lines Zheng58 and Qi319 by Agrobacterium-mediated transformation. The maize ubiquitin promoter controlled them. The transgenic maize plants showed higher betaine aldehyde dehydrogenase activity and grew better than wild-type plants under $\mathrm{NaCl}$ stress. Compared with wild type, transgenic plants have higher fresh weight under salt stress, lower malondialdehyde content, lower relative conductivity, higher chlorophyll content, higher plant height, and higher grain. It is indicated that the expression of $\mathrm{BADH}$ gene in maize seedlings enhances these plants' salt tolerance. Zhang and Liu (2011) transferred a gene that simultaneously expressed human CYP2E1 and glutathione S-transferase (GST) into alfalfa plants from hypocotyl segments by using an Agrobacterium transformation system. The $p K H C G$ transgenic alfalfa plants' resistance to mixed contaminants (heavy metal-organic compounds) was significantly increased compared to the transgenic alfalfa plants expressing a single gene (GST or CYP2E1) and the nontransgenic control plants. The $p K H C G$ alfalfa plants showed strong resistance to the mixtures of cadmium (Cd) and trichloroethylene (TCE), and these mixtures were metabolized 
TABLE 2 | Giant reed and hyperaccumulator plants differ in accumulating heavy metal.

\begin{tabular}{|c|c|c|c|c|c|c|}
\hline & $\mathrm{Ni}(\mathbf{m g} / \mathbf{k g})$ & $\mathrm{Pb}$ (mg/kg) & $\mathrm{Cd}(\mathbf{m g} / \mathbf{k g})$ & As $(\mathbf{m g} / \mathbf{k g})$ & $\mathrm{Zn}$ (mg/kg) & $\mathrm{Cr}(\mathrm{mg} / \mathrm{kg})$ \\
\hline Giant reed $^{a-d}$ & $<193$ & $<515$ & $<64.12$ & $<61.96$ & $<118$ & $<34$ \\
\hline Hyperaccumulator plants ${ }^{\mathrm{e}}$ & $>1,000$ & $>1,000$ & $>100$ & $>1,000$ & $>3,000$ & $>300$ \\
\hline
\end{tabular}

aAlshaal et al. (2013)

${ }^{b}$ Guo and Miao (2010)

${ }^{c}$ Barbosa et al. (2015)

${ }^{d}$ Sidella et al. (2017)

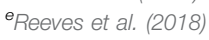

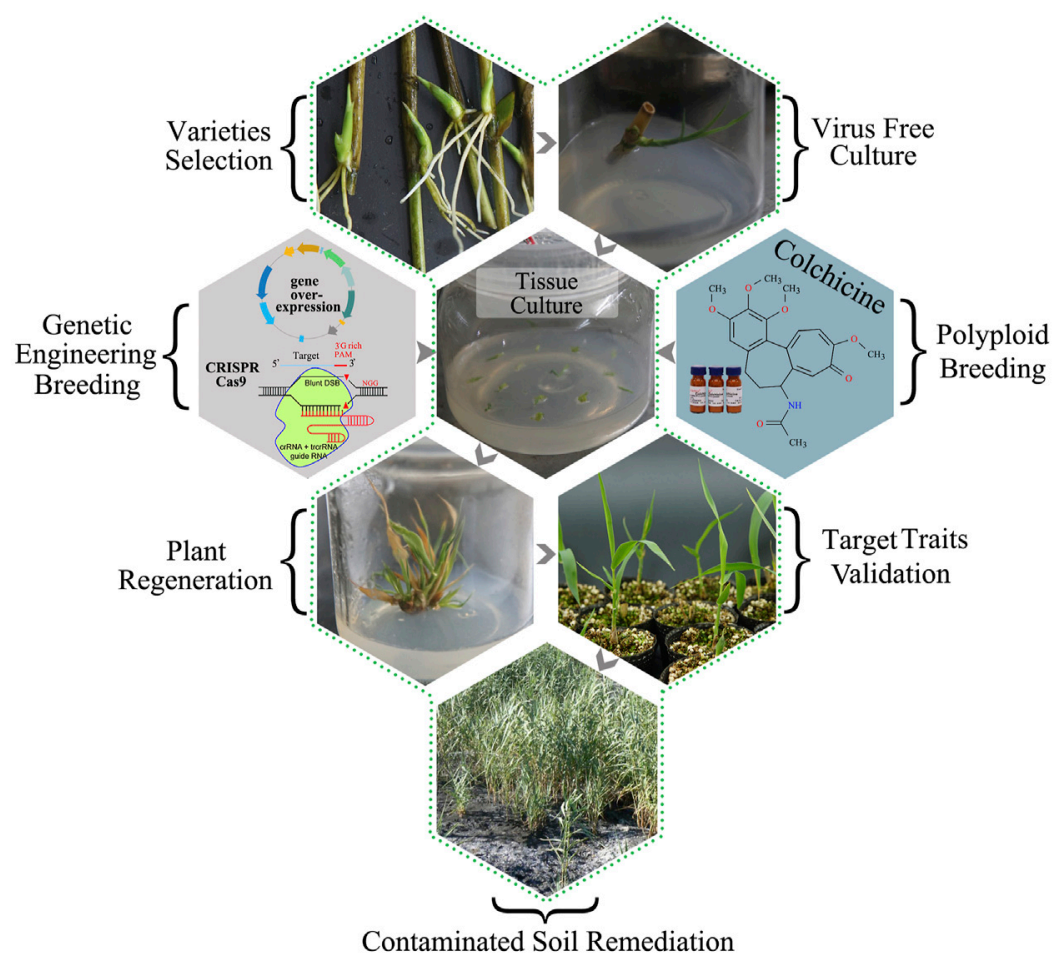

FIGURE 4 | Flow chart of breeding giant reed resistant varieties using transgenic technology.

by the combination of introduced GST and CYP2E1. He et al. (2001) introduced the bacterial mercuric reductase (merA) into tobacco and the transgenic tobacco plants were resistant to high levels of mercuric chloride and removed mercury from water solutions and soil by volatilization. Czako et al. (2006) cointroduced the bacterial mercuric reductase $(\operatorname{mer} A)$ and organomercurial lyase (merB) genes into the saltmarsh cordgrass (Spartina alterniflora) by Agrobaterium-mediated transformation and the resultant heavy metal resistant transgenic tissue showed enhanced tolerance to both mercuric and phenylmercuric salts. Kim et al. (2011) transferred the MuSI gene into tobacco, and Escherichia coli cells overexpressing MuSI were more resistant to $\mathrm{Cd}$ than wild-type cells transfected with vector alone. $\mathrm{MuSI}$ transgenic plants were also more resistant to Cd. MuSI transgenic tobacco plants absorbed less Cd than wild type plants. In transgenic plants, cadmium transport from root to shoot was reduced, thereby avoiding the toxicity of cadmium. These results indicated that $M u S I$ transgenic tobacco plants tolerate Cd by reduced translocation from roots to shoots and reduced uptake and/or increased immobilization of $\mathrm{Cd}$ in the roots. Peng et al. (2018) isolated a TpNRAMP5 from dwarf Polish wheat (DPW, Triticum polonicum L.) and transferred it to Arabidopsis thaliana. The expression of TPNRAMP5 in Arabidopsis significantly increased the content of $\mathrm{Cd}, \mathrm{Co}$, and $\mathrm{Mn}$ in roots, stems, and whole plants but did not affect the content of $\mathrm{Fe}$ and $\mathrm{Zn}$. These results indicate that TpNRAMP5 is a metal transporter that enhances $\mathrm{Cd}$, Co, and $\mathrm{Mn}$ accumulation but does not enhance the accumulation of $\mathrm{Zn}$ and Fe. With the continuous advancement of biotechnology, it is an excellent way to improve the ecological environment by cultivating plants through genetically modified technology.

The use of plants to remove contaminants from contaminated water and soil may be a promising strategy. Giant reed can absorb heavy metals, reduce the $\mathrm{pH}$ of the saline soil and purify the water. It should be mentioned that some disadvantages of giant reed cannot be overlooked. There is still a gap between giant reed and 
hyperaccumulator plants accumulating most of heavy metal (Table 2). Although recent studies report giant reed as moderately tolerant to salt stress and biomass yield was not decreased, surprisingly, high salt stress caused yield heavy losses (Di Mola et al., 2018). There is an urgent need, but it is still a significant challenge for giant reed breeding because giant reed seeds cannot breed in most areas. The reproduction only occurs by the vegetative growth of rhizomes and of stem nodes of broken canes. Because of this, the genotypic diversity among clonal populations is expected to be very low (Sicilia et al., 2019). Considering the chromosome number of giant reed is diverse and ploidy levels of giant reed may depend on the different territory in which the plant has grown and may depend on its evolutionary history, polyploidy breeding in giant reed is an excellent choice (Corno et al., 2014). As the regeneration system of giant reed has been published so far, and an optimized particle bombardment protocol for gene transfer with embryogenic calli was recently reported in giant reed (Takahashi and Takamizo, 2012), genetic engineering could represent a feasible option for giant improvement reed (Figure 4). Biotic and abiotic stress tolerance is the minimum required trait, which is not tricky in

\section{REFERENCES}

Ahluwalia, S. S., and Goyal, D. (2007). Microbial and Plant Derived Biomass for Removal of Heavy Metals from Wastewater. Bioresour. Technol. 98, 2243-2257. doi:10.1016/j.biortech.2005.12.006

Ahmed, M. J. (2016). Potential of Arundo donax L. Stems as Renewable Precursors for Activated Carbons and Utilization for Wastewater Treatments: Review. J. Taiwan Inst. Chem. Eng. 63, 336-343. doi:10.1016/j.jtice.2016.03.030

Al-Snafi, A. E. (2015). The Constituents and Biological Effects of Arundo Donax-A Review. Int. J. Phytopharmacy Res. 6, 34-40.

Ali, H., Khan, E., and Sajad, M. A. (2013). Phytoremediation of Heavy MetalsConcepts and Applications. Chemosphere 91, 869-881. doi:10.1016/j. chemosphere.2013.01.075

Alshaal, T., Domokos-Szabolcsy, É., Márton, L., Czakó, M., Kátai, J., Balogh, P., et al. (2013). Phytoremediation of Bauxite-Derived Red Mud by Giant Reed. Environ. Chem. Lett. 11, 295-302. doi:10.1007/s10311-013-0406-6

Alshaal, T., Elhawat, N., Domokos-Szabolcsy, É., Kátai, J., Márton, L., Czako, M., et al. (2015). "Giant Reed (Arundo donax L.): A Green Technology for Clean Environment," in Phytoremediation: Management of Environmental Contaminants, Vol I. Editors A. A. Ansari, S. S. Gill, R. Gill, G. R. Lanza, and L. Newman. (Springer Science + Business Media B. V.), 3-20. doi:10.1007/978-3319-10395-2_1

An, P. (2019). Review, analyse and Forecast for Aluminum Market. Light Met. 5, 1-11. doi:10.13662/j.cnki.qjs.2019.05.001

Angelini, L. G., Ceccarini, L., and Bonari, E. (2005). Biomass Yield and Energy Balance of Giant Reed (Arundo donax L.) Cropped in Central Italy as Related to Different Management Practices. Eur. J. Agron. 22, 375-389. doi:10.1016/j.eja. 2004.05.004

Angelini, L. G., Ceccarini, L., Nassi o Di Nasso, N., and Bonari, E. (2009). Comparison of Arundo donax L. And Miscanthus X Giganteus in a LongTerm Field Experiment in Central Italy: Analysis of Productive Characteristics and Energy Balance. Biomass and Bioenergy 33, 635-643. doi:10.1016/j. biombioe.2008.10.005

Antal, G., Fári, M. G., and Domokos-Szabolcsy, É. (2018). Obtention of New Ornamental Leaf Variants of Giant Reed (Arundo donax L.) Originated from Somatic Embryogenesis and Their Photosynthetic Parameters. Int. J. Hortic. Sci. 24. doi:10.31421/ijhs/24/1-2./1542

Assirelli, A., Civitarese, V., Caracciolo, G., Sannino, M., and Faugno, S. (2019). Mechanical Harvesting Line Setting of Giant Reeds. Appl. Sci. 9, 5425. doi:10. 3390/app9245425 molecular breeding. These traits and candidate target genes are reviewed in front of this article.

\section{AUTHOR CONTRIBUTIONS}

SH, JL conceived the original structure of the review. QJ, DL helped with literature data collection. DZ prepared the manuscript. All authors have read and agreed to the published version of the manuscript.

\section{FUNDING}

This research was supported by the National Natural Science Foundation of China (41867054), the National Key R\&D Program of China (2019YFC0507503), the Natural Science Foundation of Guangxi, China (2018GXNSFAA281108), Science and Technology Major Project of Guangxi (Guike AA20161004), and the Science and Technology Major Project of Guilin, China (20180101-2).

Assirelli, A., Santangelo, E., Spinelli, R., Acampora, A., Croce, S., Civitarese, V., et al. (2013). Mechanization of Rhizome Extraction in Giant Reed (Arundo donax L.) Nurseries. Appl. Eng. Agric. 29, 489-494. doi:10.13031/aea.29.9797

Atma, W., Larouci, M., Meddah, B., Benabdeli, K., and Sonnet, P. (2017). Evaluation of the Phytoremediation Potential of Arundo donax L. For Nickel-Contaminated Soil. Int. J. Phytoremediation 19, 377-386. doi:10. 1080/15226514.2016.1225291

Bajaj, S., Targolli, J., Liu, L.-F., Ho, T.-H. D., and Wu, R. (1999). Transgenic Approaches to Increase Dehydration-Stress Tolerance in Plants. Mol. Breed. 5, 493-503. doi:10.1023/a:1009660413133

Baker, A. J. M., Mcgrath, S. P., Sidoli, C. M. D., and Reeves, R. D. (1994). The Possibility of In Situ Heavy Metal Decontamination of Polluted Soils Using Crops of Metal-Accumulating Plants. Resour. Conservation Recycling 11, 41-49. doi:10.1016/0921-3449(94)90077-9

Baker, A. J. M., McGrath, S. P., Reeves, R. D., and Smith, J. A. C. (2000). "Metal Hyperaccumulator Plants: A Review of the Ecology and Physiology of a Biological Resource for Phytoremediation of Metal Polluted Soils," in Phytoremediation of Contaminated Soil and Water. Editors N. Terry and G. Banuelos (Boca Raton, FL: Lewis), 85-108.

Balogh, E., Herr, J. M., Jr, Czakó, M., and Márton, L. (2012). Defective Development of Male and Female Gametophytes in Arundo donax L. (POACEAE). Biomass and Bioenergy 45, 265-269. doi:10.1016/j.biombioe.2012.06.010

Barbagallo, S., Barbera, A. C., Cirelli, G. L., Milani, M., and Toscano, A. (2014). Reuse of Constructed Wetland Effluents for Irrigation of Energy Crops. Water Sci. Technol. 70, 1465-1472. doi:10.2166/wst.2014.383

Barbosa, B., Boléo, S., Sidella, S., Costa, J., Duarte, M. P., Mendes, B., et al. (2015). Phytoremediation of Heavy Metal-Contaminated Soils Using the Perennial Energy Crops Miscanthus Spp. And Arundo donax L. Bioenerg. Res. 8, 1500-1511. doi:10.1007/s12155-015-9688-9

Barbosa, B., Fernando, A., Lino, J., Costa, J., Sidella, S., Boléo, S., et al. (2013) "Phytoremediation Response of Arundodonax L. In Soils Contaminated with Zinc and Chromium,".in Proceedings of the 21st European Biomass Conference and Exhibition, Setting the course for a Biobased Economy, Copenhagen, Denmark, June 3-7, 2013, 3-7.

Barreca, F., and Fichera, C. R. (2013). Wall Panels of Arundo donax L. For Environmentally Sustainable Agriculture Buildings: Thermal Performance Evaluation. J. Food Agric. Environ. 11, 1353-1357.

Barreca, F., Martinez Gabarron, A., Flores Yepes, J. A., and Pastor Pérez, J. J. (2019). Innovative Use of Giant Reed and Cork Residues for Panels of Buildings in Mediterranean Area. Resour. Conservation Recycling 140, 259-266. doi:10.1016/ j.resconrec.2018.10.005 
Barreca, F. (2012). Use of Giant Reed Arundo Donax L. In Rural Constructions. Agric. Eng. Int. CIGR J. 14, 46-52.

Basso, M. C., Cerrella, E. G., Buonomo, E. L., Bonelli, P. R., and Cukierman, A. L. (2005). Thermochemical Conversion ofArundo Donaxinto Useful Solid Products. Energ. Sourc. 27, 1429-1438. doi:10.1080/009083190523280

Bell, G. P. (1998). Ecology and Management of Arundo donax, and Approaches to Riparian Habitat Restoration in Southern California. Online resource: https:// www.invasive.org/gist/moredocs/arudon 01.pdf (Accessed October 2018).

Bonanno, G. (2012). Arundo donax as a Potential Biomonitor of Trace Element Contamination in Water and Sediment. Ecotoxicology Environ. Saf. 80, 20-27. doi:10.1016/j.ecoenv.2012.02.005

Borso, F. D., Di Marzo, C., Zuliani, F., Danuso, F., and Baldini, M. (2018). Harvest Time and Ensilage Suitability of Giant Reed and Miscanthus for Bio-Methane Production and Characterization of Digestate for Agronomic Use. Agron. Res. $16,22-40$.

Bradshaw, J. E. (2017). Plant Breeding: Past, Present and Future. Euphytica 213, 60. doi:10.1007/s10681-016-1815-y

Breseghello, F., and Coelho, A. S. G. (2013). Traditional and Modern Plant Breeding Methods with Examples in Rice (Oryza Sativa L.). J. Agric. Food Chem. 61, 8277-8286. doi:10.1021/jf305531j

Brunori, C., Cremisini, C., Massanisso, P., Pinto, V., and Torricelli, L. (2005). Reuse of a Treated Red Mud Bauxite Waste: Studies on Environmental Compatibility. J. Hazard. Mater. 117, 55-63. doi:10.1016/j.jhazmat.2004.09.010

Bukhari, R., and Kour, H. (2019). Polyploidy in Agriculture: With Special Reference to Mulberry. J. Pharmacognosy Phytochemistry 8, 1795-1808. doi:10.20546/ijcmas.2019.805.101

Burakov, A. E., Galunin, E. V., Burakova, I. V., Kucherova, A. E., Agarwal, S., Tkachev, A. G., et al. (2018). Adsorption of Heavy Metals on Conventional and Nanostructured Materials for Wastewater Treatment Purposes: A Review. Ecotoxicology Environ. Saf. 148, 702-712. doi:10.1016/j.ecoenv. 2017.11.034

Cano-Ruiz, J., Ruiz Galea, M., Amorós, M. C., Alonso, J., Mauri, P. V., and Lobo, M. C. (2020). Assessing Arundo donax L. In Vitro-tolerance for Phytoremediation Purposes. Chemosphere 252, 126576. doi:10.1016/j.chemosphere.2020.126576

Castaldi, P., Silvetti, M., Manzano, R., Brundu, G., Roggero, P. P., and Garau, G. (2018). Mutual Effect of Phragmites Australis, Arundo donax and Immobilization Agents on Arsenic and Trace Metals Phytostabilization in Polluted Soils. Geoderma 314, 63-72. doi:10.1016/j.geoderma.2017.10.040

Cavallaro, V., Tringali, S., and PatanĖ, C. (2011). Large-scalein Vitropropagation of Giant Reed (Arundo donaxL.), a Promising Biomass Species. J. Hortic. Sci. Biotechnol. 86, 452-456. doi:10.1080/14620316.2011.11512787

Chen, C., Li, B., and Mo, H. (2016). The Establishment of Rapid Propagation Systems for Arundo donax. South. Hortic. 27, 01-05.

Clijsters, H., and Van Assche, F. (1985). Inhibition of Photosynthesis by Heavy Metals. Photosynth. Res. 7, 31-40. doi:10.1007/bf00032920

Coppa, E., Astolfi, S., Beni, C., Carnevale, M., Colarossi, D., Gallucci, F., et al. (2020). Evaluating the Potential Use of Cu-Contaminated Soils for Giant Reed (Arundo donax, L.) Cultivation as a Biomass Crop. Environ. Sci. Pollut. Res. 27, 8662-8672. doi:10.1007/s11356-019-07503-x

Corno, L., Lonati, S., Riva, C., Pilu, R., and Adani, F. (2016). Giant Cane (Arundo donax L.) Can Substitute Traditional Energy Crops in Producing Energy by Anaerobic Digestion, Reducing Surface Area and Costs: A Full-Scale Approach. Bioresour. Technol. 218, 826-832. doi:10.1016/j.biortech.2016.07.050

Corno, L., Pilu, R., and Adani, F. (2014). Arundo donax L.: a Non-food Crop for Bioenergy and Bio-Compound Production. Biotechnol. Adv. 32, 1535-1549. doi:10.1016/j.biotechadv.2014.10.006

Corno, L., Pilu, R., Tambone, F., Scaglia, B., and Adani, F. (2015). New Energy Crop Giant Cane (Arundo donax L.) Can Substitute Traditional Energy Crops Increasing Biogas Yield and Reducing Costs. Bioresour. Technol. 191, 197-204. doi:10.1016/j.biortech.2015.05.015

Cristaldi, A., Conti, G. O., Cosentino, S. L., Mauromicale, G., Copat, C., Grasso, A., et al. (2020). Phytoremediation Potential of Arundo donax (Giant Reed) in Contaminated Soil by Heavy Metals. Environ. Res. 185, 109427. doi:10.1016/j. envres.2020.109427

Cui, J., and Wang, L. (2013). Laboratory Study on the Performance of Domestic Wastewater Biofilters Made of Arundo donax L. AmmApplied Mech. Mater. 295298, 1104-1109. doi:10.4028/www.scientific.net/amm.295-298.1104
Curt, M., Sanz, M., Mosquera, F., Mauri, P., Plaza, A., Aguado, P., et al. (2013). "Harvest Mechanisation of Arundo donax L. In Spain," in 21st European Biomass Conference and Exhibition, Copenhagen, Denmark, June 3-7, 2013.

Czakó, M., Feng, X., He, Y., Liang, D., and Márton, L. (2006). Transgenic Spartina Alterniflora for Phytoremediation. Environ. Geochem. Health 28, 103-110. doi:10.1007/s10653-005-9019-8

Czakó, M., and Márton, L. (2011). Subtropical and Tropical Reeds for biomassEnergy Crops. Cambridge, United Kingdom: RSC Publishing Royal Society of Chemistry, 322-340.

Dahlawi, S., Naeem, A., Rengel, Z., and Naidu, R. (2018). Biochar Application for the Remediation of Salt-Affected Soils: Challenges and Opportunities. Sci. Total Environ. 625, 320-335. doi:10.1016/j.scitotenv.2017.12.257

Danelli, T., Sepulcri, A., Masetti, G., Colombo, F., Sangiorgio, S., Cassani, E., et al. (2021). Arundo donax L. Biomass Production in a Polluted Area: Effects of Two Harvest Timings on Heavy Metals Uptake. Appl. Sci. 11, 1147. doi:10.3390/ app11031147

Delplace, G., Schreck, E., Pokrovsky, O. S., Zouiten, C., Blondet, I., Darrozes, J. et al. (2020). Accumulation of Heavy Metals in Phytoliths from Reeds Growing on Mining Environments in Southern Europe. Sci. Total Environ. 712, 135595. doi:10.1016/j.scitotenv.2019.135595

Dhiren, K., and Singh, H. B. (2015). Traditional Knowledge, Economic Prospects and Conservation Issues on Giant Reed (Arundo donax Linnaeus) in Manipur, Northeast India. Pleione 9, 481-493.

Di, H., Tian, Y., Zu, H., Meng, X., Zeng, X., and Wang, Z. (2015). Enhanced Salinity Tolerance in Transgenic Maize Plants Expressing a BADH Gene from Atriplex Micrantha. Euphytica 206, 775-783. doi:10.1007/s10681-015-1515-z

Di Mola, I., Guida, G., Mistretta, C., Giorio, P., Albrizio, R., Visconti, D., et al. (2018). Agronomic and Physiological Response of Giant Reed (Arundo donax L.) to Soil Salinity. Ital. J. Agron. 13, 31-39. doi:10.4081/ija.2018.995

Dixit, R., Wasiullah, D., Malaviya, D., Pandiyan, K., Singh, U., Sahu, A., et al. (2015). Bioremediation of Heavy Metals from Soil and Aquatic Environment: an Overview of Principles and Criteria of Fundamental Processes. Sustainability 7, 2189-2212. doi:10.3390/su7022189

Domokos-Szabolcsy, É., Fári, M., Márton, L., Czakó, M., Veres, S., Elhawat, N., et al. (2018). Selenate Tolerance and Selenium Hyperaccumulation in the Monocot Giant Reed (Arundo donax), a Biomass Crop Plant with Phytoremediation Potential. Environ. Sci. Pollut. Res. 25, 31368-31380. doi:10.1007/s11356-018-3127-3

Dubey, S., Shri, M., Gupta, A., Rani, V., and Chakrabarty, D. (2018). Toxicity and Detoxification of Heavy Metals during Plant Growth and Metabolism. Environ. Chem. Lett. 16, 1169-1192. doi:10.1007/s10311-018-0741-8

Duke, J., and Wain, K. (1981). Medicinal Plants of the World. 3 Vol. Computer Index with More than 85,000 entriesPlants Genetics and Germplasm Institute. Beltsville, MD: Agriculture Research Service.

El Sheikha, A. (2017). Traceability and Inspection: For Safer Food Supply. Asia Pac. J. Food Saf. Secur. 3, 1-2.

Etesami, H. (2018). Bacterial Mediated Alleviation of Heavy Metal Stress and Decreased Accumulation of Metals in Plant Tissues: Mechanisms and Future Prospects. Ecotoxicology Environ. Saf. 147, 175-191. doi:10.1016/j.ecoenv.2017. 08.032

Facchini, P. (1941). La canna gentile per la produzione della cellulosa nobile, l'impresa agricolo industriale di Torviscosa. Milano, Italy: SNIA VISCOSA.

Fidele, M., and Audra, P. (2020). Residual Wastewater Treatment by an Aquatic Plant System in Tropical Area: Assessment of Arundo Donax and Pennisetum Purpureum Schumach. Int. J. Water Wastewater Treat. 6. doi:10.16966/23815299.168

Fiorentino, N., Fagnano, M., Adamo, P., Impagliazzo, A., Mori, M., Pepe, O., et al. (2013). Assisted Phytoextraction of Heavy Metals: Compost and Trichoderma Effects on Giant Reed (Arundo donax L.) Uptake and Soil N-Cycle Microflora. Ital. J. Agron. 8, e29. doi:10.4081/ija.2013.e29

Flores, J. A., Pastor, J. J., Martinez-Gabarron, A., Gimeno-Blanes, F. J., RodríguezGuisado, I., and Frutos, M. J. (2011). Arundo donax Chipboard Based on UreaFormaldehyde Resin Using under $4 \mathrm{~mm}$ Particles Size Meets the Standard Criteria for Indoor Use. Ind. Crops Prod. 34, 1538-1542. doi:10.1016/j.indcrop. 2011.05.011

Fu, F., and Wang, Q. (2011). Removal of Heavy Metal Ions from Wastewaters: a Review. J. Environ. Manage. 92, 407-418. doi:10.1016/j.jenvman.2010.11.011 
Ghosh, M., and Singh, S. (2005). A Review on Phytoremediation of Heavy Metals and Utilization of It's by Products. Asian J. Energ. Environ 6, 18

Grottola, C. M., Giudicianni, P., Pindozzi, S., Stanzione, F., Faugno, S., Fagnano, M., et al. (2019). Steam Assisted Slow Pyrolysis of Contaminated Biomasses: Effect of Plant Parts and Process Temperature on Heavy Metals Fate. Waste Manag. 85, 232-241. doi:10.1016/j.wasman.2018.12.028

Guarino, F., Miranda, A., Castiglione, S., and Cicatelli, A. (2020). Arsenic Phytovolatilization and Epigenetic Modifications in Arundo donax L. Assisted by a PGPR Consortium. Chemosphere 251, 126310. doi:10.1016/j. chemosphere.2020.126310

Gubišová, M., Čičková, M., Klčová, L., and Gubiš, J. (2016). In vitro tillering-An Effective Way to Multiply High-Biomass Plant Arundo donax. Ind. Crops Prod. $81,123-128$.

Guo, Z.-H., and Miao, X.-F. (2010). Growth Changes and Tissues Anatomical Characteristics of Giant Reed (Arundo donax L.) in Soil Contaminated with Arsenic, Cadmium and Lead. J. Cent. South. Univ. Technol. 17, 770-777. doi:10. 1007/s11771-010-0555-8

Gupta, V. K., Ali, I., Saleh, T. A., Nayak, A., and Agarwal, S. (2012). Chemical Treatment Technologies for Waste-Water Recycling-An Overview. RSC Adv. 2, 6380-6388. doi:10.1039/c2ra20340e

Han, Z., and Wang, C. (2007). Accumulation and Distribution of Cadmium, Lead, Mercury, and Copper in Arundo donax of Different Ecotype. Ecol. Environ. 16, 1092-1097.

He, Y. K., Sun, J. G., Feng, X. Z., Czakó, M., and Márton, L. (2001). Differential Mercury Volatilization by Tobacco Organs Expressing a Modified Bacterial merA Gene. Cell Res 11, 231-236. doi:10.1038/sj.cr.7290091

Herrera-Alamillo, M. Á., and Robert, M. L. (2012). Liquid In Vitro Culture for the Propagation of Arundo donax. Methods Mol. Biol. 877, 153-160. doi:10.1007/ 978-1-61779-818-4_12

Hu, W., Nie, Q., Huang, B., Shu, X., and He, Q. (2018). Mechanical and Microstructural Characterization of Geopolymers Derived from Red Mud and Fly Ashes. J. Clean. Prod. 186, 799-806. doi:10.1016/j.jclepro.2018.03.086

Idris, S. M., Jones, P. L., Salzman, S. A., and Allinson, G. (2012b). Performance of the Giant Reed (Arundo donax) in Experimental Wetlands Receiving Variable Loads of Industrial Stormwater. Water Air Soil Pollut. 223, 549-557. doi:10. 1007/s11270-011-0881-y

Idris, S. M., Jones, P. L., Salzman, S. A., Croatto, G., and Allinson, G. (2012a). Evaluation of the Giant Reed (Arundo donax) in Horizontal Subsurface Flow Wetlands for the Treatment of Recirculating Aquaculture System Effluent. Environ. Sci. Pollut. Res. 19, 1159-1170. doi:10.1007/s11356-011-0642-x

Jain, B., Singh, A. K., Kim, H., Lichtfouse, E., and Sharma, V. K. (2018). Treatment of Organic Pollutants by Homogeneous and Heterogeneous Fenton Reaction Processes. Environ. Chem. Lett. 16, 947-967. doi:10.1007/s10311-018-0738-3

Jenssen, P. D., Mæhlum, T., and Krogstad, T. (1993). Potential Use of Constructed Wetlands for Wastewater Treatment in Northern Environments. Water Sci. Technol. 28, 149-157. doi:10.2166/wst.1993.0223

Jesus, J. M., Cassoni, A. C., Danko, A. S., Fiúza, A., and Borges, M.-T. (2017). Role of Three Different Plants on Simultaneous Salt and Nutrient Reduction from Saline Synthetic Wastewater in Lab-Scale Constructed Wetlands. Sci. Total Environ. 579, 447-455. doi:10.1016/j.scitotenv.2016.11.074

Kempe, K., and Gils, M. (2011). Pollination Control Technologies for Hybrid Breeding. Mol. Breed. 27, 417-437. doi:10.1007/s11032-011-9555-0

Khairul, M. A., Zanganeh, J., and Moghtaderi, B. (2019). The Composition, Recycling and Utilisation of Bayer Red Mud. Resour. Conservation Recycling 141, 483-498. doi:10.1016/j.resconrec.2018.11.006

Kim, Y.-N., Kim, J.-S., Seo, S.-G., Lee, Y., Baek, S.-W., Kim, I.-S., et al. (2011). Cadmium Resistance in Tobacco Plants Expressing the MuSI Gene. Plant Biotechnol. Rep. 5, 323-329. doi:10.1007/s11816-011-0186-z

Leto, C., Tuttolomondo, T., Bella, S. L., Leone, R., and Licata, M. (2013). Growth ofArundo donaxL. andCyperus alternifoliusL. In a Horizontal Subsurface Flow Constructed Wetland Using Pre-treated Urban Wastewater-A Case Study in Sicily (Italy). Desalination Water Treat. 51, 7447-7459. doi:10.1080/19443994. 2013.792134

Lewandowski, I., Scurlock, J. M. O., Lindvall, E., and Christou, M. (2003). The Development and Current Status of Perennial Rhizomatous Grasses as Energy Crops in the US and Europe. Biomass and Bioenergy 25, 335-361. doi:10.1016/ s0961-9534(03)00030-8
Li, C., Xiao, B., Wang, Q., Yao, S., and Wu, J. (2014). Phytoremediation of Zn-And Cr-Contaminated Soil Using Two Promising Energy Grasses. Water Air Soil Pollut. 225, 1-12. doi:10.1007/s11270-014-2027-5

Li, P., Qian, H., and Wu, J. (2018). Conjunctive Use of Groundwater and Surface Water to Reduce Soil Salinization in the Yinchuan Plain, North-West China. Int. J. Water Resour. Develop. 34, 337-353. doi:10.1080/07900627.2018. 1443059

Liao, J., Zhang, D., Mallik, A., Huang, Y., He, C., and Xu, G. (2017). Growth and Nutrient Removal of Three Macrophytes in Response to Concentrations and Ratios of N and P. Int. J. Phytoremediation 19, 651-657. doi:10.1080/15226514. 2016.1278424

Liu, L., Fan, X.-D., Wang, F.-W., Wang, N., Dong, Y.-Y., Liu, X.-M., et al. (2013). Coexpression of ScNHX1 and ScVP in Transgenic Hybrids Improves Salt and Saline-Alkali Tolerance in Alfalfa (Medicago Sativa L.). J. Plant Growth Regul. 32, 1-8. doi:10.1007/s00344-012-9270-z

Liu, Y.-N., Guo, Z.-H., Xiao, X.-Y., Wang, S., Jiang, Z.-C., and Zeng, P. (2017). Phytostabilisation Potential of Giant Reed for Metals Contaminated Soil Modified with Complex Organic Fertiliser and Fly Ash: A Field Experiment. Sci. Total Environ. 576, 292-302. doi:10.1016/j.scitotenv.2016.10.065

Longin, C. F. H., Mühleisen, J., Maurer, H. P., Zhang, H., Gowda, M., and Reif, J. C. (2012). Hybrid Breeding in Autogamous Cereals. Theor. Appl. Genet. 125, 1087-1096. doi:10.1007/s00122-012-1967-7

Luo, Z., Wang, T., Yi, L.-B., Peng, X.-L., Ding, G.-X., and Liu, S.-B. (2018). Effects of Growth Regulators on the Survival Rate of Cuttings from Lateral Branches of Giant Reed ( Arundo donax) in Summer. J. Biol. 35, 23. doi:10.3969/j.issn.20951736.2018.03.023

Mabhungu, L., Adam, E., and Newete, S. (2019). Monitoring of Phytoremediating Wetland Macrophytes Using Remote Sensing in the Case of Common Reed and Giant Reed: a Review. Appl. Ecol. Environ. Res. 17, 7957-7972. doi:10.15666/ aeer/1704_79577972

Mahmood, N. M. Q. (2010). Phytoremediation of Arsenic (As) and Mercury (Hg) Contaminated Soil. World Appl. Sci. J. 8, 113-118.

Marton, L., and Czako, M. (2002). Sustained Totipotent Regenerable Tissue Culture of Arundo donax (Giant Reed) and Totipotent Tissue and Plants Produced Therefrom. United States Patent Application: 20020166149.

Mavrogianopoulos, G., Vogli, V., and Kyritsis, S. (2002). Use of Wastewater as a Nutrient Solution in a Closed Gravel Hydroponic Culture of Giant Reed (Arundo donax). Bioresour. Technol. 82, 103-107. doi:10.1016/s09608524(01)00180-8

Miao, Y., Xiao, X.-Y., Miao, X.-F., Guo, Z.-H., and Wang, F.-Y. (2012). Effect of Amendments on Growth and Metal Uptake of Giant Reed (Arundo donax L.) Grown on Soil Contaminated by Arsenic, Cadmium and Lead. Trans. Nonferrous Met. Soc. China 22, 1462-1469. doi:10.1016/S1003-6326(11) $61342-3$

Mir, T. A., Jan, M., and Dhyani, S. (2018). A Comprehensive Account of EthnoMedicinal Uses of Monocot Flora (Reported from February-June) of Karwapani Forest Doon Valley-Uttarakhand. SERBD-International J. Multidisciplinary Sci. 1, 22-27.

Mirza, N., Mahmood, Q., Pervez, A., Ahmad, R., Farooq, R., Shah, M. M., et al. (2010). Phytoremediation Potential of Arundo donax in Arsenic-Contaminated Synthetic Wastewater. Bioresour. Technol. 101, 5815-5819. doi:10.1016/j. biortech.2010.03.012

Mishra, T., and Pandey, V. C. (2019). "Phytoremediation of Red Mud Deposits through Natural Succession," in Phytomanagement of Polluted Sites (Amsterdam, Netherlands: Elsevier), 409-424. doi:10.1016/b978-0-12813912-7.00016-8

Mukhopadhyay, S., and Maiti, S. (2010). Phytoremediation of Metal Mine Waste. Appl. Ecol. Environ. Res. 8, 207-222.

Muradian, R., and Martinez-Alier, J. (2001). Trade and the Environment: from a "Southern" Perspective. Ecol. Econ. 36, 281-297. doi:10.1016/s0921-8009(00) 00229-9

Nagajyoti, P. C., Lee, K. D., and Sreekanth, T. V. M. (2010). Heavy Metals, Occurrence and Toxicity for Plants: a Review. Environ. Chem. Lett. 8, 199-216. doi:10.1007/s10311-010-0297-8

Nelson, M., Odum, H. T., Brown, M. T., and Alling, A. (2001). "Living off the Land": Resource Efficiency of Wetland Wastewater Treatment. Adv. Space Res. 27, 1547-1556. doi:10.1016/s0273-1177(01)00246-0 
Nikhade, C., and Makde, K. (2014). Reproductive Behavior of Arundo donax L. Int. J. Researches Biosciences, Agric. Technol. 2, 670-679. doi:10.29369/ijrbat.2014. 02.II.0043

Nouri, H., Chavoshi Borujeni, S., Nirola, R., Hassanli, A., Beecham, S., Alaghmand, S., et al. (2017). Application of Green Remediation on Soil Salinity Treatment: A Review on Halophytoremediation. Process Saf. Environ. Prot. 107, 94-107. doi:10.1016/j.psep.2017.01.021

O'Connor, D., Peng, T., Zhang, J., Tsang, D. C. W., Alessi, D. S., Shen, Z., et al. (2018). Biochar Application for the Remediation of Heavy Metal Polluted Land: a Review of In Situ Field Trials. Sci. Total Environ. 619-620, 815-826. doi:10. 1016/j.scitotenv.2017.11.132

Papazoglou, E. G., Karantounias, G. A., Vemmos, S. N., and Bouranis, D. L. (2005). Photosynthesis and Growth Responses of Giant Reed (Arundo donax L.) to the Heavy Metals Cd and Ni. Environ. Int. 31, 243-249. doi:10.1016/j.envint.2004. 09.022

Paramguru, R. K., Rath, P. C., and Misra, V. N. (2004). Trends in Red Mud Utilization - a Review. Mineral. Process. Extractive Metall. Rev. 26, 1-29. doi:10. 1080/08827500490477603

Peng, F., Wang, C., Zhu, J., Zeng, J., Kang, H., Fan, X., et al. (2018). Expression of TpNRAMP5, a Metal Transporter from Polish Wheat (Triticum Polonicum L.), Enhances the Accumulation of $\mathrm{Cd}$, Co and $\mathrm{Mn}$ in Transgenic Arabidopsis Plants. Planta 247, 1395-1406. doi:10.1007/s00425-018-2872-3

Perdue, R. E. (1958). Arundo Donax-Source of Musical Reeds and Industrial Cellulose. Econ. Bot. 12, 368-404. doi:10.1007/bf02860024

Pompeiano, A., Landi, M., Meloni, G., Vita, F., Guglielminetti, L., and Guidi, L. (2017). Allocation Pattern, Ion Partitioning, and Chlorophyll a Fluorescence in Arundo donax L. In Responses to Salinity Stress. Plant Biosyst. - Int. J. Dealing all Aspects Plant Biol. 151, 613-622. doi:10.1080/11263504.2016.1187680

Pu, G., Zeng, D., Mo, L., Liao, J., Xu, G., Huang, Y., et al. (2018). Cadmium Accumulation and its Effects on Physiological Characteristics of Arundo donax L. In a Simulated Wetland. Glob. NEST J. 21, 423-429. doi:10.30955/gnj.002580

$\mathrm{Pu}$, G., Zhang, D., Zeng, D., Xu, G., and Huang, Y. (2017). Physiological Response of Arundo donax L. To Thallium Accumulation in a Simulated Wetland. Mar. Freshw. Res. 69, 714-720. doi:10.1071/MF17093

Quave, C. L., Plano, L. R. W., Pantuso, T., and Bennett, B. C. (2008). Effects of Extracts from Italian Medicinal Plants on Planktonic Growth, Biofilm Formation and Adherence of Methicillin-Resistant Staphylococcus aureus. J. Ethnopharmacology 118, 418-428. doi:10.1016/j.jep.2008.05.005

Quinn, L. D., Straker, K. C., Guo, J., Kim, S., Thapa, S., Kling, G., et al. (2015). Stress-tolerant Feedstocks for Sustainable Bioenergy Production on Marginal Land. Bioenerg. Res. 8, 1081-1100. doi:10.1007/s12155-014-9557-y

Rabhi, M., Karray-Bouraoui, N., Medini, R., Attia, H., Abdelly, C., and Smaoui, A. (2010). Seasonal Variations in Phytodesalination Capacity of Two Perennial Halophytes in Their Natural Biotope. J. Biol. Res. 14, 181.

Rai, P. K., Lee, S. S., Zhang, M., Tsang, Y. F., and Kim, K.-H. (2019). Heavy Metals in Food Crops: Health Risks, Fate, Mechanisms, and Management. Environ. Int. 125, 365-385. doi:10.1016/j.envint.2019.01.067

Reeves, R. D., Van Der Ent, A., and Baker, A. J. M. (2018). "Global Distribution and Ecology of Hyperaccumulator Plants," in Agromining: Farming for Metals. Heidelberg, Germany; Springer, 75-92.

Roberto, P. (2012). Giant Reed (Arundo donax L.): A Weed Plant or a Promising Energy Crop? Afr. J. Biotechnol. 11, 9163-9174. doi:10.5897/AJB11.4182

Sahu, R. C., Patel, R. K., and Ray, B. C. (2010). Neutralization of Red Mud Using CO2 Sequestration Cycle. J. Hazard. Mater. 179, 28-34. doi:10.1016/j.jhazmat. 2010.02 .052

Salgot, M., and Folch, M. (2018). Wastewater Treatment and Water Reuse. Curr. Opin. Environ. Sci. Health 2, 64-74. doi:10.1016/j.coesh.2018.03.005

San Martín, C., Gourlie, J. A., and Barroso, J. (2019). Control of Volunteer Giant Reed (Arundo donax). Invasive Plant Sci. Manag. 12, 43-50. doi:10.1017/inp. 2018.36

Sánchez, J., Curt, M. D., and Fernández, J. (2017). Approach to the Potential Production of Giant Reed in Surplus Saline Lands of Spain. Gcb Bioenergy 9, 105-118. doi:10.1111/gcbb.12329

Sarathambal, C., Khankhane, P. J., Gharde, Y., Kumar, B., Varun, M., and Arun, S. (2017). The Effect of Plant Growth-Promoting Rhizobacteria on the Growth, Physiology, and Cd Uptake of Arundo donax L. Int. J. Phytoremediation 19, 360-370. doi:10.1080/15226514.2016.1225289
Saxena, G., Purchase, D., Mulla, S. I., Saratale, G. D., and Bharagava, R. N. (2019). Phytoremediation of Heavy Metal-Contaminated Sites: Eco-Environmental Concerns, Field Studies, Sustainability Issues, and Future Prospects. Rev. Environ. Contam. Toxicol. 249, 71-131. doi:10.1007/398_2019_24

Shahid, M. J., Tahseen, R., Siddique, M., Ali, S., Iqbal, S., and Afzal, M. (2019). Remediation of Polluted River Water by Floating Treatment Wetlands. Water Supply 19, 967-977. doi:10.2166/ws.2018.154

Shatalov, A. A., and Pereira, H. (2006). Papermaking Fibers from Giant Reed (Arundo donax L.) by Advanced Ecologically Friendly Pulping and Bleaching Technologies. BioResources 1, 45-61.

Shilpi, S., Lamb, D., Bolan, N., Seshadri, B., Choppala, G., and Naidu, R. (2019). Waste to Watt: Anaerobic Digestion of Wastewater Irrigated Biomass for Energy and Fertiliser Production. J. Environ. Manag. 239, 73-83. doi:10. 1016/j.jenvman.2019.02.122

Sicilia, A., Testa, G., Santoro, D. F., Cosentino, S. L., and Piero, A. R. L. (2019). RNASeq Analysis of Giant Cane Reveals the Leaf Transcriptome Dynamics under Long-Term Salt Stress. BMC Plant Biol. 19, 355. doi:10.1186/s12870-0191964-y

Sidella, S., Cosentino, S. L., Fernando, A., Costa, J., and Barbosa, B. (2017). "Phytoremediation of Soils Contaminated with Lead by Arundo donax L," in WASTES-solutions, Treatments and Opportunities II-Selected Papers from the 4th Edition of the International Conference Wastes: Solutions, Treatments and Opportunities, Porto, Portugal, September 25-26, 2017 (London, United Kingdom: CRC Press), 25-26.

Sidella, S., Fernando, A., Barbosa, B., Costa, J., Boléo, S., Bandarra, V., et al. (2013). "Phytoremediation Response of Arundo donax in Soils Contaminated with Lead," in Proceedings of the 21st European Biomass Conference and Exhibition, Setting the Course for a Biobased Economy, Copenhagen. Denmark, June 3-7, 2013 (Munich, Germany: ETA-Renewable Energies and WIP-Renewable Energies, 385-387.

Singh, A., Kuhad, R. C., and Ward, O. P. (2009). "Biological Remediation of Soil: an Overview of Global Market and Available Technologies," in Advances in Applied Bioremediation. Soil Biology. Editors A. Singh and O. P. Ward (Berlin, Germany: Springer), 1-19. doi:10.1007/978-3-540-89621-0_1

Singh, H. B. (2003). Herbal Medicine of Manipur A Colour Encyclopedia. New Delhi, India: Daya Publishing House.

Sinha, S. C. (1996). Medicinal Plants of Manipur. Manipur, India: Mass \& Sinha Publications.

Speck, O., and Spatz, H.-C. (2004). Damped Oscillations of the Giant Reed Arundo donax (Poaceae). Am. J. Bot. 91, 789-796. doi:10.3732/ajb.91.6.789

Stottmeister, U., Wießner, A., Kuschk, P., Kappelmeyer, U., Kästner, M., Bederski, O., et al. (2003). Effects of Plants and Microorganisms in Constructed Wetlands for Wastewater Treatment. Biotechnol. Adv. 22, 93-117. doi:10.1016/j. biotechadv.2003.08.010

Sumiahadi, A., and Acar, R. (2018). A Review of Phytoremediation Technology: Heavy Metals Uptake by Plants. IOP Conf. Ser. Earth Environ. Sci. 142, 012023. doi:10.1088/1755-1315/142/1/012023

Takahashi, W., and Takamizo, T. (2012). "Molecular Breeding of Grasses by Transgenic Approaches for Biofuel Production," in Transgenic Plants-Advances And Limitations. Editor Y. O. Çiftçi (Rijeka, Croatia: InTech), 91-116.

Tang, H. (2000). Study on Cutting Seedling Technology of Giant Reed. For. Sci. Technol. 2, 13-14. doi:10.13456/j.cnki.lykt.2000.02.004

Tanner, C. C. (1996). Plants for Constructed Wetland Treatment Systems - A Comparison of the Growth and Nutrient Uptake of Eight Emergent Species. Ecol. Eng. 7, 59-83. doi:10.1016/0925-8574(95)00066-6

Taylor, N., Chavarriaga, P., Raemakers, K., Siritunga, D., and Zhang, P. (2004). Development and Application of Transgenic Technologies in Cassava. Plant Mol. Biol. 56, 671-688. doi:10.1007/s11103-004-4872-x

Tejada, M., Garcia, C., Gonzalez, J. L., and Hernandez, M. T. (2006). Use of Organic Amendment as a Strategy for Saline Soil Remediation: Influence on the Physical, Chemical and Biological Properties of Soil. Soil Biol. Biochem. 38, 1413-1421. doi:10.1016/j.soilbio.2005.10.017

Thakur, S., Singh, L., Ab Wahid, Z., Siddiqui, M. F., Atnaw, S. M., and Din, M. F. M. (2016). Plant-driven Removal of Heavy Metals from Soil: Uptake, Translocation, Tolerance Mechanism, Challenges, and Future Perspectives. Environ. Monit. Assess. 188, 206. doi:10.1007/s10661-016-5211-9 
Tiwari, S., and Lata, C. (2018). Heavy Metal Stress, Signaling, and Tolerance Due to Plant-Associated Microbes: an Overview. Front. Plant Sci. 9, 452. doi:10.3389/ fpls.2018.00452

Toscano, A., Marzo, A., Milani, M., Cirelli, G. L., and Barbagallo, S. (2015). Comparison of Removal Efficiencies in Mediterranean Pilot Constructed Wetlands Vegetated with Different Plant Species. Ecol. Eng. 75, 155-160. doi:10.1016/j.ecoleng.2014.12.005

Ullah, A., Heng, S., Munis, M. F. H., Fahad, S., and Yang, X. (2015). Phytoremediation of Heavy Metals Assisted by Plant Growth Promoting (PGP) Bacteria: a Review. Environ. Exp. Bot. 117, 28-40. doi:10.1016/j.envexpbot.2015.05.001

Verslues, P. E., Agarwal, M., Katiyar-Agarwal, S., Zhu, J., and Zhu, J.-K. (2006). Methods and Concepts in Quantifying Resistance to Drought, Salt and Freezing, Abiotic Stresses that Affect Plant Water Status. Plant J. 45, 523-539. doi:10.1111/j.1365-313x.2005.02593.x

Wang, M., Zhang, D., Dong, J., and Tan, S. K. (2018). Application of Constructed Wetlands for Treating Agricultural Runoff and Agro-Industrial Wastewater: a Review. Hydrobiologia 805, 1-31. doi:10.1007/s10750-017-3315-z

Wang, Q., Duan, L., Ruihua, L., and Wu, J. (2008). Comparison of Nutrient Uptake from Rural Domestic Sewage of Aquatic Plants. Acta Agriculturae BorealiSinica 23, 217-222.

Wang, R., Li, H., and Sun, H. (2019). Bismuth: Environmental Pollution and Health Effects. Encyclopedia Environ. Health 1, 415-423. doi:10.1016/b978-012-409548-9.11870-6

Williams, C., Biswas, T., Schrale, G., Virtue, J., and Heading, S. (2008). "Use of Saline Land and Wastewater for Growing a Potential Biofuel Crop (Arundo donax L.)," in Proceedings of Irrigation Australia Conference, Melbourne, Australia, May 20-22, 2008

Williams, C. M. J., Biswas, T. K., Black, I. D., Marton, L., Czako, M., Harris, P. L., et al. (2009). Use of Poor Quality Water to Produce High Biomass Yields of Giant Reed (Arundo donax L.) on Marginal Lands for Biofuel or Pulp/paper. Acta Hortic. 806, 595-602. doi:10.17660/actahortic.2009.806.74

Xian, K., Su, J., Fu, C., Huang, N., Gong, Q., and He, J. (2018). Techniques for Rapid Propagation of Arundo donax. Guihaia 38, 128-134.

Xie, W., Xie, F., Huang, L., Gao, X., Chen, J., Ma, X., et al. (2012). Purification Efficiency of Micro-polluted River Water by Horizontal Subsurface-Flow Constructed Wetland with Arundo donax. China Water \& Wastewater 28, 69-71. doi:10.3969/j.issn.1000-4602.2012.21.020

Xue, S., Zhu, F., Kong, X., Wu, C., Huang, L., Huang, N., et al. (2016). A Review of the Characterization and Revegetation of Bauxite Residues (Red Mud). Environ. Sci. Pollut. Res. 23, 1120-1132. doi:10.1007/s11356-015-4558-8
Yamaguchi, H. (2018). Mutation Breeding of Ornamental Plants Using Ion Beams. Breed. Sci. 68, 71-78. doi:10.1270/jsbbs. 17086

Yang, L., and Li, Y. (2014). Anaerobic Digestion of Giant Reed for Methane Production. Bioresour. Technol. 171, 233-239. doi:10.1016/j.biortech.2014. 08.051

Yang, Q., Li, Z., Lu, X., Duan, Q., Huang, L., and Bi, J. (2018). A Review of Soil Heavy Metal Pollution from Industrial and Agricultural Regions in China: Pollution and Risk Assessment. Sci. Total Environ. 642, 690-700. doi:10.1016/j. scitotenv.2018.06.068

Yang, Y., Wang, Y., Zhu, M., and Lu, Y. (2016). A Study on Callus Induction and Plant Regeneration in Giant Reed ( Arundo donax). Pratacultural Sci. 33, 1332-1341. doi:10.11829/j.issn.10010629.20150720

Yin, K., Wang, Q., Lv, M., and Chen, L. (2019). Microorganism Remediation Strategies towards Heavy Metals. Chem. Eng. J. 360, 1553-1563. doi:10.1016/j. cej.2018.10.226

Zema, D. A., Bombino, G., Andiloro, S., and Zimbone, S. M. (2012). Irrigation of Energy Crops with Urban Wastewater: Effects on Biomass Yields, Soils and Heating Values. Agric. Water Manag. 115, 55-65. doi:10.1016/j.agwat.2012.08.009

Zhang, Y., and Liu, J. (2011). Transgenic Alfalfa Plants Co-expressing Glutathione S-Transferase (GST) and Human CYP2E1 Show Enhanced Resistance to Mixed Contaminates of Heavy Metals and Organic Pollutants. J. Hazard. Mater. 189, 357-362. doi:10.1016/j.jhazmat.2011.02.042

Zhang, Y., Sivakumar, M., Yang, S., Enever, K., and Ramezanianpour, M. (2018). Application of Solar Energy in Water Treatment Processes: A Review. Desalination 428, 116-145. doi:10.1016/j.desal.2017.11.020

Zhao, G., Huang, X., Tang, Z., Huang, Q., Niu, F., and Wang, X. (2018). Polymerbased Nanocomposites for Heavy Metal Ions Removal from Aqueous Solution: a Review. Polym. Chem. 9, 3562-3582. doi:10.1039/c8py00484f

Conflict of Interest: The authors declare that the research was conducted in the absence of any commercial or financial relationships that could be construed as a potential conflict of interest.

Copyright (c) 2021 Zhang, Jiang, Liang, Huang and Liao. This is an open-access article distributed under the terms of the Creative Commons Attribution License (CC $B Y)$. The use, distribution or reproduction in other forums is permitted, provided the original author(s) and the copyright owner(s) are credited and that the original publication in this journal is cited, in accordance with accepted academic practice. No use, distribution or reproduction is permitted which does not comply with these terms. 